OPEN ACCESS

Edited by:

Hirokazu Kanegane,

Tokyo Medical and Dental University,

Japan

Reviewed by:

Ivan K. Chinn,

Baylor College of Medicine,

United States

Alessandro Aiuti,

Vita-Salute San Raffaele University,

Italy

*Correspondence:

Hanae Miyazawa hsugiura.1202@gmail.com

Specialty section:

This article was submitted to

Primary Immunodeficiencies,

a section of the journal

Frontiers in Immunology

Received: 25 September 2021

Accepted: 28 October 2021

Published: 16 November 2021

Citation:

Miyazawa H and Wada T (2021)

Reversion Mosaicism in Primary

Immunodeficiency Diseases.

Front. Immunol. 12:783022.

doi: 10.3389/fimmu.2021.783022

\section{Reversion Mosaicism in Primary Immunodeficiency Diseases}

\author{
Hanae Miyazawa * and Taizo Wada \\ Department of Pediatrics, School of Medicine, Institute of Medical, Pharmaceutical and Health Sciences, Kanazawa \\ University, Kanazawa, Japan
}

Reversion mosaicism has been reported in an increasing number of genetic disorders including primary immunodeficiency diseases. Several mechanisms can mediate somatic reversion of inherited mutations. Back mutations restore wild-type sequences, whereas second-site mutations result in compensatory changes. In addition, intragenic recombination, chromosomal deletions, and copy-neutral loss of heterozygosity have been demonstrated in mosaic individuals. Revertant cells that have regained wild-type function may be associated with milder disease phenotypes in some immunodeficient patients with reversion mosaicism. Revertant cells can also be responsible for immune dysregulation. Studies identifying a large variety of genetic changes in the same individual further support a frequent occurrence of reversion mosaicism in primary immunodeficiency diseases. This phenomenon also provides unique opportunities to evaluate the biological effects of restored gene expression in different cell lineages. In this paper, we review the recent findings of reversion mosaicism in primary immunodeficiency diseases and discuss its clinical implications.

Keywords: reversion, reversion mosaicism, somatic reversion, primary immunodeficiency diseases, selective advantage, gene therapy

\section{INTRODUCTION}

Genetic mosaicism refers to an individual who has developed from a unique zygote but carries two or more cell types with different genotypes (1). This phenomenon is derived from postzygotic mutations, which can occur during embryonic development or during postnatal life (1). Based on the tissue distributions, genetic mosaicism is categorized into three types: gonadal mosaicism, gonosomal mosaicism, and somatic mosaicism (1). In gonadal and gonosomal mosaicism, postzygotic mutations affect the germline cells; therefore, mutant alleles can be transmitted to the offspring (1). However, in somatic mosaicism, postzygotic mutations occur only in somatic cells and may cause a disease related to the mutated gene, but they are not transmitted to the offspring (1). Reversion mosaicism refers to somatic mosaicism due to a reversion to normal of an inherited pathogenic mutation (2). In reversion mosaicism, reversion mutations partially or fully restore the effect of the primary disease-causing variant (2). The most common and simplest type of reversion is a true back mutation, which refers to the reversion of the germline mutation site to the wild-type sequence (3) (Figure 1A). As an alternative, a site-specific substitution is a nucleotide substitution at the specific germline mutation site, which restores the original amino acid sequence or the alternation to a less deleterious amino acid than in the original germline mutation (3) (Figure 1B). Reversion mutation also results from 
second-site mutation, which occurs at a different site from the germline mutation but within the coding or noncoding regions of the same gene, and results in a compensatory change that abrogates the deleterious effect of the germline mutation (3) (Figure 1C). In autosomal recessive disorders caused by compound heterozygous mutations, intragenic recombination can lead to reversion through the generation of a wild-type allele with the other allele carrying both germline mutations (3) (Figure 1D). Copy-neutral loss of heterozygosity $(\mathrm{CN}-\mathrm{LOH})$ can eliminate the chromosomal region encompassing the germline mutation and replace it with a copy of the wild-type chromosome from the other parent (3) (Figure 1E). Furthermore, in autosomal dominant disorders caused by gain-offunction mutations, the elimination of a dominant germline mutation can be achieved by aneuploidy resulting from chromosomal structural mutations such as chromosomal deletion and chromothripsis (3) (Figure 1F).

Reversion mosaicism has been described in several disorders that affect the hematopoietic and nonhematopoietic systems such as Bloom syndrome, Fanconi anemia, dyskeratosis congenita, tyrosinemia, and epidermolysis bullosa (3, 4). Reversion mosaicism has frequently been found in diseases that affect highly generating tissues and organ systems, which may reflect the significant cell proliferation and the high mutagenicity of these tissues (5). Primary immunodeficiency diseases (PIDs) are a major category of disorders in which somatic reversion has been frequently described (4). The first case of reversion mosaicism in PIDs was recognized because of a milder than expected clinical phenotype in a patient with adenosine deaminase (ADA) deficiency (6). Reversion mosaicism has subsequently been found in some PIDs such as X-linked severe combined immunodeficiency (X-SCID) (5, 7-13), recombination activating gene 1 (RAG1) deficiency $(14,15)$, CD3 $\zeta$ deficiency (16-19), and Wiskott-Aldrich syndrome (WAS) (20-36). The establishment of reversion mosaicism has modified the clinical phenotype of these disorders in which revertant cells have a selective advantage in vivo (5). The beneficial consequence of somatic reversion has paved the way to gene therapy, based on gene addition through viralmediated transfer of the wild-type copy of the gene, which has been applied for curative therapy for ADA-SCID, X-SCID, and WAS $(37,38)$. Here, we review the newer findings of reversion mosaicism in PIDs and describe clinical implications for understanding this phenomenon.
A

\section{Back mutation}

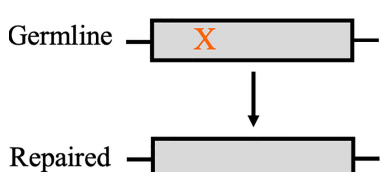

D

Intragenic recombination

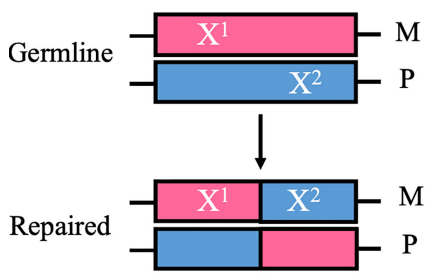

Site-specific substitution

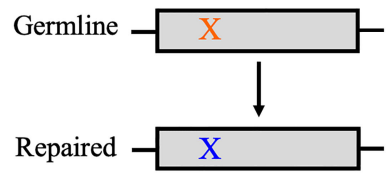

E

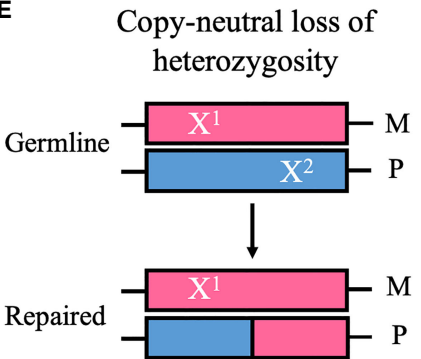

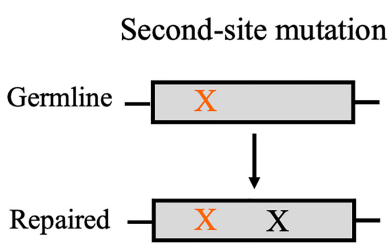

$\mathbf{F}$

Structural mutation

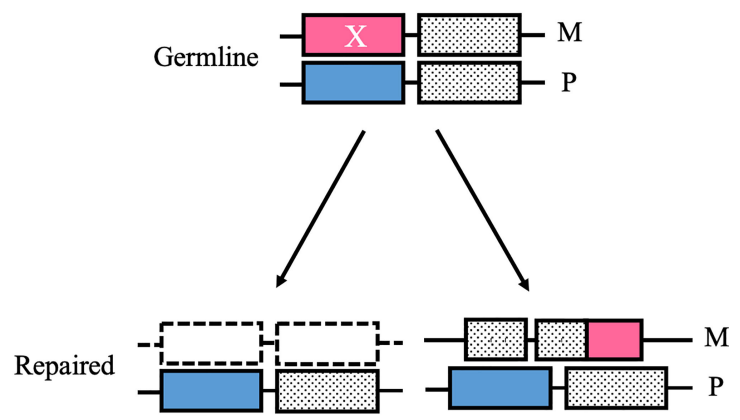

Chromosomal deletion Chromothripsis

FIGURE 1 | Schematic diagrams of the reversion mechanism. (A) A germ line point mutation (orange "X") is changed to the wild-type sequence (i.e., back mutation) (B) A germ line point mutation substitutes for a nucleotide other than the wild-type sequence (blue " $X$ "), which restores the original amino acid sequence or results in the alternation to a less deleterious amino acid than in the original germline mutation (i.e., site-specific substitution). (C) A mutation that occurs at a different site from the germline mutation but within the coding or noncoding regions of the same gene (black " $X$ ") can cause a compensatory change that abrogates the deleterious effect of the germline mutation (i.e., second-site mutation). (D) Intragenic recombination can lead to reversion through the generation of a wild-type allele, whereas the other allele carries both germline mutations (i.e., $X^{1}$ and $X^{2}$ ). (E) Copy-neutral loss of heterozygosity can eliminate the chromosomal region encompassing the germline mutation and replace it a copy of the wild-type chromosome from the other parent. (F) A structural mutation such as chromosomal deletion and chromothripsis can abrogate a deleterious gain-of-function mutation ("X") by modifying the chromosomal structure. M, maternal allele; P, paternal allele. (A) Back mutation, (B) Site-specific substitution, (C) Second-site mutation, (D) Intragenic recombination, (E) Copy-neutral loss of heterozygosity, (F) Structural mutation. 


\section{PIDS ASSOCIATED WITH REVERSION MOSAICISM}

\section{WAS}

WAS is a rare X-linked disorder characterized by thrombocytopenia, eczema, susceptibility to infections, autoimmunity, and lymphoreticular neoplasia. The responsible gene, WAS, encodes the WAS protein (WASp). WASp, an essential regulator of actin cytoskeleton remodeling, is only expressed in hematopoietic cells and is involved in multiple functions in immune cells. WASpdeficient T-cells fail to form and stabilize the immunological synapse, thereby resulting in defective polarization of T-cells toward antigen-presenting cells. WASp also has a critical role in Tand B-cell interaction, B-cell homeostasis, phagocytosis, cytolytic function of natural killer (NK) cells, and FAS-mediated apoptosis. Various roles of WASp in innate and acquired immunity have been progressively reported, but the full function of WASp remains to be clarified (39-42).

Somatic reversion seems to occur frequently in WAS patients, as can be expected from the fact that at least 40 cases in 17 studies have been published to date (20-36) (Table 1). The European Society for Immunodeficiencies survey of 40 groups/laboratories worldwide documented that WASp reversions occurred in approximately $11 \%(30 / 272)$ of WAS patients (22). WASpexpressing revertant cells have been detected as early as 3 months and as late as the 4th decade of life. Revertant cells have been detected among T-cells, B-cells, and NK cells. However, T-cells are the most common subset of lymphocytes to contain revertant cells with percentages ranging from $5 \%$ to $80 \%$ (Table 1). The fraction of revertant $\mathrm{CD} 4^{+}$and $\mathrm{CD} 8^{+} \mathrm{T}$-cells is diverse among each case. In approximately one-half of the observed cases, more than one lymphoid lineage included revertant cells; however, no cases of revertant cells involving myeloid cells have been reported $(4,22,39)$ (Table 1). The revertant cells can accumulate over time and are preferentially represented among memory T-cells, regulatory T-cells, and NK cells, which indicates that a reversion mutation can confer significant selective advantage to the revertant cell population when it restores WASp function $(27,29,30,33-35)$. The expansion of revertant cells, which has been observed in in vitro culture, also supports this notion (21). An important note is that the appearance of WASp revertant cells in circulation does not necessarily confer a clinical benefit for the WAS phenotype. In many patients, the presence of revertant cells does not prevent the occurrence of life-threatening complications, whereas several patients have presented with a milder clinical course than expected, based on their mutations (40). Clinical outcome after reversion probably depends on at least following factors: the timing of reversion during cell differentiation process, the type and function of cells in which reversion occurs, and the size and diversity of revertant cell population (27). In addition, autoimmune manifestations may be caused by the presence of residual WASp-negative autoreactive lymphocyte per se, even if WASp-expressing revertant cells accumulate (27, 28). These findings will offer valuable perspectives on the possible clinical outcomes of gene therapy for WAS patients.

Based on a molecular point of view, back mutations and second-site mutations are equally common mechanisms that restore WASp expression $(4,39)$ (Table 1). The mutational hotspots for reversion have not been indicated; however, 30\% of reversions occur in exon 10, as distinct from the fact that most loss-of-function mutations in WAS, primarily missense mutations, are in exons 1 to $4(22,43)$. Of note, more than 30 different genotypic changes have been detected in primary T-cell clones from an adult WAS patient carrying the c.995C $>\mathrm{T}$ nonsense mutation in exon $10(24,26)$. However, revertant cells with multiple genotypes within the same individual has been identified in two WAS siblings who carried a c.58C $>\mathrm{T}$ nonsense mutation in exon 1 and in other two siblings who carried a c.G1305del mutation, which is predicted to cause a truncated protein that lacked the C-terminal verprolin homology, cofilin homology, and acidic domains $(23,25)$. This phenomenon also has been identified in other immunological disorders (e.g., CD3 $\zeta$ deficiency, X-SCID, and RAG1 deficiency) and nonimmunological disorders (e.g., epidermolysis bullosa) $(11,14,19,44)$. Conventional direct sequencing analysis may not

TABLE 1 | Somatic revertant cases of WAS.

\begin{tabular}{|c|c|c|c|}
\hline Number of patients & Type of reversion & Revertant cell & Reference \\
\hline 1 & Second-site mutation & Lymphocytes & $(20)$ \\
\hline 1 & Back mutation & $\mathrm{CD}^{+} \mathrm{T}, \mathrm{CD}^{+} \mathrm{T}$ & $(21)$ \\
\hline 3 & A 6-bp deletion (DNA slippage) & $\mathrm{CD}^{+} \mathrm{T}, \mathrm{CD}^{+} \mathrm{T}$ & $(29,31)$ \\
\hline 2 & Second-site mutation (19-bp deletion) & $\mathrm{CD}^{+} \mathrm{T}, \mathrm{CD} 8^{+} \mathrm{T}, \mathrm{B}$ & $(30,32)$ \\
\hline 1 & Back mutation (1-bp deletion) & NK & (33) \\
\hline 1 & Second-site mutation & $\mathrm{CD}^{+} \mathrm{T}, \mathrm{CD}^{+} \mathrm{T}, \mathrm{NK}$ & (34) \\
\hline 1 & Back mutation (1-bp insertion) & $\mathrm{T}, \mathrm{B}, \mathrm{NK}$ & (35) \\
\hline 1 & Back mutation & $\mathrm{CD}^{+} \mathrm{T}, \mathrm{CD}^{+} \mathrm{T}, \gamma \delta \mathrm{T}$ & (36) \\
\hline $30^{\mathrm{a}}$ & Back mutation or second-site mutation & $\mathrm{T}, \mathrm{B}, \mathrm{NK}$ & $(22)$ \\
\hline 2 & Multiple second-site mutations & $\mathrm{CD}^{+} \mathrm{T}, \mathrm{CD} 8^{+} \mathrm{T}, \mathrm{B}, \mathrm{NK}$ & (23) \\
\hline 1 & Multiple reversions (back mutation, site-specific substitutions and second-site mutations) & $\mathrm{CD}^{+} \mathrm{T}, \mathrm{CD}^{+} \mathrm{T}, \mathrm{B}$ & $(24,26)$ \\
\hline 2 & Multiple second-site mutations & $\mathrm{CD}^{+} \mathrm{T}, \mathrm{CD} 8^{+} \mathrm{T}, \mathrm{B}$ & $(25)$ \\
\hline 1 & Second-site mutation & $\mathrm{CD}^{+} \mathrm{T}, \mathrm{CD}^{+} \mathrm{T}$ & $(27)$ \\
\hline 1 & Back mutation & $\mathrm{CD}^{+} \mathrm{T}, \mathrm{CD}^{+} \mathrm{T}, \mathrm{NK}$ & (28) \\
\hline
\end{tabular}

a Some cases overlap.

WAS, Wiskott-Aldrich syndrome; NK, natural killer. 
allow the detection of multiple changes if they do not represent a significant fraction of existing genotypes. Therefore, a possibility is that the frequency of multiple revertant genotypes in WAS (and possibly other genetic disorders) has been under-reported because of technical reasons. More sensitive and efficient technologies such as deep sequencing technologies and droplet digital polymerase chain reaction (PCR) can be effective for detecting minimal fraction in reversion mosaicism. However, the fact that the clinical history of WAS patients often allows long-term management in the absence of resolutive treatment may allow sufficient time for revertant cells of diverse genotypes to individually accumulate $(26,40)$.

The reason for the high incidence of reversion mosaicism in WAS, compared to other PIDs, is unclear. The possible mutagenic effect of chronic antibiotic exposure or the high proliferation rate in lymphoid cells and consequently increased DNA polymerase mistakes, which are derived from inadequate immune response of WAS patients to infectious agents, may have a causative role in mutagenicity in WAS patients (40). However, no known involvement of WASp in DNA replication, proofreading, and DNA repair exists, and the general mutation rate does not appear to be increased in WAS patients (26). In addition to cytoplasmic functions, several nuclear functions of WASp such as gene transcription and the maintenance of genomic stability have recently been elucidated (45-52). Recent research has demonstrated that nuclear WASp is critical in preventing the accumulation of a genome-destabilizing nucleic acid structure in human T-cells that is called the "R-loop" (i.e., a three-stranded nucleic acid structure consisting of an RNA : DNA duplex and a displaced nontemplate single strand DNA) (51). It also has an important role in correcting existing double strand breaks in human B-cells (52). Moreover, another study revealed a novel function of WASp in the DNA-damage-induced Golgi dispersal response, and its disruption as a contributor to radiosensitivity in $\mathrm{T}$ - and B-cells (53). WASp accordingly has critical functions in maintaining a stable genome in human $\mathrm{T}$ and B-cells. The precise mechanism in the high frequency of reversion mosaicism in WAS patients remains unclear; however, WASp-deficiency-induced genomic instability may have an important role in the high incidence of somatic reversions in WAS patients.

\section{ADA Deficiency}

ADA deficiency is an autosomal recessive disorder that represents a SCID phenotype caused by the excessive accumulation of toxic purine nucleoside metabolites. Enzyme replacement therapy (ERT) with polyethylene glycol-ADA eliminates toxic metabolites and protects lymphocytes, thereby restoring the immune function. ERT is efficient for temporal adjunct therapy before hematopoietic stem cell transplantation (HSCT) or gene therapy $(6,54-58)$. In the middle of 1990s, Hirschhorn et al. reported two unrelated ADA-SCID patients who presented with progressive clinical improvement and biochemical and immunological remission $(6,54)$. They believe that the patients' clinical course could have been modified by somatic reversion in which revertant cells had a selective advantage; however, because of the absence of parental genetic analysis, a cause of the genetic mosaicism in one of the patients could not be distinguished from a postzygotic somatic mutation $(6,54)$.

ERT has been used because it causes a rapid improvement in immune reconstitution, even in somatic mosaicisms caused by reversion mutations. In three of four revertant patients previously reported who underwent ERT, wild-type or second-site revertant cells decreased markedly during ERT, although its biochemical and immunological effects and clinical outcomes differed among them (55-58). This finding highlights the possibility that ERT reduces the selective advantage of revertant cells. However, immune reconstitution and clinical improvement in these patients could depend on several factors such as the lineage of cells in which reversion occurred and the duration of ADA exposure. These findings provide insights into the immunological and clinical effects of gene therapy, especially in the management of ADA patients by combining gene therapy with ERT, with regard to the appropriate timing and duration of ERT.

Gene therapy is a therapeutic strategy for ADA-SCID patients and increasing evidence suggests that $\mathrm{T}$ memory stem cells $\left(\mathrm{T}_{\mathrm{SCM}}\right)$ are expected to be a potential target because of its long-persisting memory and stem-cell nature (59). Notably, recent study with ADA-SCID patients uncovered that gene-corrected $\mathrm{T}_{\mathrm{SCM}}$ can persist and preserve functional T-cell pool in vivo for up to 12 years without oncogenic feature (59). This finding indicates that $\mathrm{T}_{\mathrm{SCM}}$ gene correction is a crucial strategy for the T-cell-based gene therapy.

\section{X-SCID}

$\mathrm{X}$-SCID is the most frequent form of SCID, which is caused by mutations in the gene encoding the common gamma chain $(\gamma c)$ of the interleukin-2 receptor (IL2RG). In the absence of a functional $\gamma \mathrm{c}$, early lymphoid progenitor cells are unable to achieve the normal development of T-cells and NK cells. Most patients who present with SCID in infancy have a poor survival beyond 2 years without immune reconstitution therapy. However, hypomorphic mutations or reversion mutations of the IL2RG gene could result in a mild phenotype (i.e., late-onset combined immunodeficiency). In previous reports, five of seven revertant patients actually recovered $\gamma c$ expression and presented with the mild phenotype (5, 7-13) (Table 2). Some of these patients exhibited polyclonal expansion of the T-cell receptor variable $\beta$ (TCR V $\beta$ ) repertoire and a restored response to mitogens $(5,11)$. In these cases, reversion may occur in progenitor T-cells before the stage in which T-cells undergo TCR rearrangement. In addition, in recently reported cases, reversion was detected in NK cells or B-cells and T-cells, thereby indicating that reversion may occur at the level of the T/NK progenitor or common lymphoid progenitor $(12,13)$. By contrast, in another report, a patient had multiple reversions with a different proportion in each cell lineage (11) (Table 2). This observation suggests that reversion may occur more frequently than previously believed and may have the potential to ameliorate immunological and clinical presentations of X-SCID.

By contrast, an adverse clinical effect of reversion was raised by the observation of an X-SCID patient who presented with an Omenn syndrome (OS)-like phenotype (9) (Table 2). In this patient, revertant T-cells were only detected in skin infiltrates, not in peripheral blood, which indicated that the clonal expansion of 
TABLE 2 | Clinical and genetic features of revertant cases of X-SCID.

\begin{tabular}{|c|c|c|c|c|}
\hline $\begin{array}{l}\text { Germline } \\
\text { mutation }\end{array}$ & $\begin{array}{l}\text { Type of } \\
\text { reversion }\end{array}$ & Revertant cell & Clinical impact & Reference \\
\hline c.343T>C & Back mutation & $\mathrm{CD}^{+}{ }^{+} \mathrm{T}, \mathrm{CD} 8^{+} \mathrm{T}$ & $\begin{array}{l}\text { Patient presented with a mild phenotype, but subsequentially underwent HSCT because of } \\
\text { recurrent infections }\end{array}$ & (7) \\
\hline IVS1+5G>A & $\begin{array}{l}\text { Second-site } \\
\text { mutation }\end{array}$ & $\begin{array}{l}\mathrm{T} \text { (only skin } \\
\text { infiltrated) }\end{array}$ & Omenn syndrome & (9) \\
\hline C. $466 \mathrm{~T}>\mathrm{C}$ & Back mutation & $\alpha \beta T, \gamma \delta \mathrm{T}$ & Mild phenotype & $(10)$ \\
\hline $\begin{array}{l}c .284- \\
15 A>G\end{array}$ & Multiple reversions & $\mathrm{CD}^{+} \mathrm{T}, \mathrm{CD}^{+} \mathrm{T}$ & Mild phenotype & $(11)$ \\
\hline c. $655 \mathrm{~T}>\mathrm{A}$ & Back mutation & $\begin{array}{l}\mathrm{CD}^{+} \mathrm{T}, \mathrm{CD} 8^{+} \mathrm{T} \\
\gamma \delta \mathrm{T}\end{array}$ & Mild phenotype & (5) \\
\hline c. $260 T>C$ & Back mutation & $\mathrm{CD}^{+} \mathrm{T}, \mathrm{CD}^{+} \mathrm{T}, \mathrm{B}$ & Mild phenotype & $(12)$ \\
\hline c. $172 \mathrm{C}>\mathrm{A}$ & Back mutation & $\mathrm{CD}^{+} \mathrm{T}, \mathrm{NK}$ & Patient died of graft failure and fungal infection after HSCT & (13) \\
\hline
\end{tabular}

X-SCID, X-linked severe combined immunodeficiency; HSCT, hematopoietic stem cell transplantation; NK, natural killer.

revertant cells in response to local factors such as infections or autoantigens may be implicated in such a distinctive phenotype. This case indicates that somatic reversion is a possible cause of clinical improvement and for diverse and complicated presentations.

\section{RAG1 Deficiency}

RAG1 is a component of the RAG complex promoting V(D)J recombination in precursor lymphocytes by which highly diverse immunoglobulins and TCR genes are generated. Severe/null defects in the RAG1 gene cause $\mathrm{T}^{-} \mathrm{B}^{-} \mathrm{SCID}$, whereas leaky mutations and somatic reversions are responsible for the development of OS $(14,15,60,61)$. In a previous report of a patient with RAG1 deficiency who presented with the OS phenotype, multiple second-site mutations that generated a partially functional RAG1 molecule could have contributed to insufficient immunological reconstitution (14). In another report, a true back mutation, which was believed to occur in a limited pool of progenitor T-cells, may have been involved in the presentation of the OS phenotype in a patient (15). Both of these patients had a restricted pattern in the TCR V $\beta$ repertoire and activated T-cell markers. In the first patient, not all mutations were commonly shared by $\mathrm{CD}^{+}$and $\mathrm{CD}^{+}$T-cells (14). However, a complete defect in RAG activity results in differentiation arrest before the stage of double-negative to double-positive transition (62). These findings suggest that other precedent mutations may be followed by these second-site mutations, which occur after CD4/CD8 lineage commitment.

\section{CD3 $\zeta$ Deficiency}

CD3 $\zeta$, also called as CD247, is a subunit of the TCR complex that is required for its assembly and for surface expression, which is important for TCR-mediated signal transduction. TCR complexes lacking the $\mathrm{CD} 3 \zeta$ chain cumulate in the Golgi apparatus instead of moving onto the plasma membrane and are shunted to lysosomes for degradation. The $\mathrm{CD} 3 \zeta$ chain contributes to peripheral T-cell activation and intrathymic Tcell differentiation. The lack of $\mathrm{CD} 3 \zeta$ expression results in a severe but incomplete block of T-cell differentiation at the double-positive stage $(16,17,63)$.

Three patients with $\mathrm{CD} 3 \zeta$ deficiency were previously found to have somatic reversion mutations in CD3Z gene (16-19). The first patient, who carried a germline mutation within the intracellular first immunoreceptor tyrosine-based activation motif domain and presented with the SCID phenotype, harbored three second-site mutations that partially rescued membranous TCR expression but functioned poorly (16). Ten percent of T-cells were revertant T-cells expressing normal levels of the TCR-CD3 complex and were polyclonal. All of the cells were $\mathrm{CD} 4^{+} \mathrm{T}$-cells carrying one of three reversion mutations. Each of the three mutations was found in populations harboring different rearrangements of TCR V $\beta$ genes. This finding suggests that the reversions may occur before the $\mathrm{V}(\mathrm{D}) \mathrm{J}$ recombination at the double-negative stage. The lack of revertant cells in $\mathrm{CD}^{+} \mathrm{T}$ cells indicates that these three mutations may probably have little selective advantage for $\mathrm{CD} 8^{+} \mathrm{T}$-cells. The second revertant case involved a germline mutation within the initiation codon, which inhibited translation. This patient harbored revertant cells with a true back mutation or a compensatory second-site mutation, which caused restoration or substitution of the initiation codon; however, the frequency of revertant cells in T-cell compartment was very low (17). Revertant T-cells are capable of expanding in response to TCR stimuli in vitro but may not be sufficient to repopulate the $\mathrm{T}$-cell compartment and achieve immunological reconstitution in vivo. The $C D 3 Z$ gene may have intrinsic mutability so as to result in multiple reversions, as reported in two patients (18). This finding has been substantiated by the latest report of a revertant patient with multiple second-site mutations who presented with the mild phenotype (19). This patient carried a homozygous 2-bp deletion mutation (c.43_44delCA) within $N$-terminal signal peptide in the $C D 3 Z$ gene. Deep sequencing analysis revealed 52 somatic variants of which 49 variants restored the reading frame, most of which retained the characteristic amino acid distribution functioning as signal peptides but were not fixed to the primary sequence. A surprising finding is that 1 year after the first analysis, 23 somatic variants, which included nine novel variants, were detected with a different proportion from that of the first analysis, which may reflect the varying antigen stimulations. The multiple variation in the amino acid sequence caused by reversion mutations may reflect that signal peptides permit the fluctuation of the amino acid sequence, which may be distinct from the integral sequence for protein function. This case demonstrates that the location of 
the germline mutation can affect the spectrum of the revertant pool.

\section{Other PIDs Presenting With the SCID Phenotype}

The first case of revertant mosaicism in Janus kinase 3 (JAK3) deficiency was reported in a consanguineous family with two affected siblings (64). They presented with a relatively mild phenotype with CD4 lymphopenia, which manifested as combined immunodeficiency. A novel homozygous missense mutation (c.3196T>C) was identified in both patients. One of these patients presented with somatic mosaicism by a back mutation in $\mathrm{CD}^{+} \mathrm{T}$-cells; in the other patient, the same back mutation was detected in $\mathrm{CD} 4^{+}$and $\mathrm{CD} 8^{+} \mathrm{T}$-cells. The patient with $\mathrm{CD}_{4}^{+}$and $\mathrm{CD} 8^{+}$revertant $\mathrm{T}$-cells presented with a milder phenotype than her counterpart. Therefore, somatic reversion in $\mathrm{CD}^{+} \mathrm{T}$-cells may have contributed to the attenuation of disease severity. However, JAK3-signaling analysis showed that the presence of revertant cells had no effect on the residual JAK3dependent signaling. Hence, the hypomorphic nature of this mutation rather than reversion mutation may have been associated with the milder phenotype in the second patient.

In a study of Chinese patients with DNA ligase IV (LIG4) deficiency, one of seven patients presented with reversion mosaicism (65). The germline genotype of this patient was a compound heterozygote (c.833G >T; c.935delC) in the LIG4 gene; however, wild-type clones and simultaneously generated clones, which contained both inherited mutations, were detected with TA cloning analysis. This finding indicates that intragenic recombination was a probable mechanism of somatic repair of LIG4 mutations. The reversion event may occur at an early stage of embryonic development because these clones were obtained from T-cells, NK cells, granulocytes, and oral mucosa cells in different proportions. However, the somatic reversion was insufficient to reconstitute clinical and immunological phenotype in this patient.

A patient with interleukin (IL)-7 receptor $\alpha$ deficiency, who had compound heterozygous mutations (one single nucleotide variant and one intragenic copy number variant involving one exon), presented with an atypical clinical course and late onset (66). Mosaicism for the wild-type allele in the single nucleotide variant position was unexpectedly identified in whole exome sequencing. However, whether it originated from somatic reversion, maternal engraftment, or both was unproven.

\section{XL-EDA-ID (NEMO Deficiency)}

$\mathrm{X}$-linked anhidrotic ectodermal dysplasia with immunodeficiency (XL-EDA-ID) is caused by hypomorphic mutations in IKBKG gene, which encodes nuclear factor- $\mathrm{KB}(\mathrm{NF}-\mathrm{\kappa B})$ essential modulator (NEMO). NEMO has an important role in activating inhibitor of NF- $\kappa B$ (I $\kappa$ B) kinase, which phosphorylates and degrades I $\mathrm{KB}$ to activate NF- $\kappa B$. A defect in NEMO causes various abnormalities in the signal transduction pathway involving NF- $\mathrm{KB}$, including the IL1 family protein receptors, the Toll-like receptors, CD40, and the tumor necrosis factor (TNF) receptor $(67,68)$. Patients with XLEDA-ID present with various immunological phenotypes such as reduced production of proinflammatory cytokines in response to lipopolysaccharide and IL-1 family protein stimulation, dysregulated immunoglobulin synthesis, defective antipolysaccharide antibody synthesis, and NK cell dysfunction $(67,68)$.

In a Japanese nationwide survey, as many as $90 \%(9 / 10)$ of XL-EDA-ID patients presented with somatic reversion mosaicism (69). In these patients, most revertant cells were detected in $\mathrm{CD}^{+}$and/or $\mathrm{CD}^{+}{ }^{+} \mathrm{T}$-cells, a low number of revertant cells was detected in B-cells, and no revertant cells were detected in monocytes. One sibling who harbored a duplication mutation in the IKBKG gene also showed reversion mutation in approximately $50 \%$ of $\mathrm{CD}^{+} 6^{+} \mathrm{NK}$ cells (70). In two siblings, the revertant $\mathrm{CD} 8^{+} \mathrm{T}$-cells primarily presented with the memory/effector phenotype and the restricted pattern of the TCR V $\beta$ repertoire $(69,70)$. The high incidence of somatic mosaicism may reflect a strong selective advantage for NEMOexpressing revertant cells in vivo, especially in the T-cell lineage. However, the precise role for NEMO in the development and homeostasis of each cell lineage has not been fully elucidated. The clinical impacts of somatic mosaicism in XL-EDA-ID patients were not demonstrated in the studies $(69,70)$.

By contrast, the clinical impact of NEMO reversion has been demonstrated in another revertant patient who presented with refractory inflammatory colitis (71). The mechanism underlying the NEMO colitis was demonstrated in a mouse model of intestinal epithelium-specific NEMO deficiency in which intestinal epithelial cells exhibited increased sensitivity to TNF $\alpha$-induced apoptosis and caused disruption of the epithelial barrier, resulting in chronic intestinal inflammation (72). In this patient, the NEMO-deficient intestinal epithelium might be further damaged by TNF $\alpha$-producing mononuclear cells because of the reversion mutation of NEMO. The patient's peripheral TNF $\alpha$-producing cells reduced with repeated antiTNF $\alpha$ antibody administrations, thereby causing the clinical improvement. Thus, NEMO reversion may have a deleterious role in the intestinal inflammation.

Owing to the presence of a pseudogene (i.e., IKBKGP1), the genetic diagnosis of XL-EDA-ID is difficult to determine when using only genomic DNA sequencing analysis. It should be confirmed by sequencing analysis of NEMO cDNA or longrange PCR amplicon using primers that do not amplify the pseudogene. The presence of somatic mosaicism can cause a misdiagnosis of XL-EDA-ID when a normal revertant cDNA sequence can be selectively amplified with PCR or when most of each cell lineage consists of NEMO-expressing revertant cells (69).

\section{LAD-1}

Leukocyte adhesion deficiency type 1 (LAD-1) is caused by a genetic defect in the ITGB2 gene, which encodes the common chain of the $\beta 2$ integrin family (CD18). The adhesion of leukocytes to the endothelium is primarily defected, thereby causing abnormal leukocyte extravasation. Patients are usually affected with recurrent bacterial infections and impaired wound healing without pus formation. The severity of the clinical phenotype is directly associated with the degree of CD18 deficiency (73). To date, five revertant patients harboring 
CD18-expressing cells have been reported in LAD-1 (74-76). The first patient had a compound heterozygous mutation and carried a reversion to the normal sequence in one of the diseasecausing mutations only within a small fraction of $\mathrm{CD}^{+} \mathrm{T}$-cells. This fraction was monoclonal, which indicated that reversion may occur in a committed hematopoietic lineage and eventually gain a selective advantage (74). In three additional patients, all of whom presented with gastrointestinal manifestations, $5 \%$ to $20 \%$ of revertant cells were detected among $\mathrm{CD}^{+} \mathrm{T}$-cells and exhibited a restricted pattern of the TCR V $\beta$ repertoire (75). In all four cases, revertant $\mathrm{CD} 8^{+} \mathrm{T}$-cells represented the memory/ effector phenotype. In addition, a functional study revealed that reversion mutations showed the recovery of superantigeninduced proliferation and adhesion to specific ligands in vitro (75). Taken together, these findings suggest that reversion mutations may exhibit functional recovery and a proliferative advantage and lead to the acquisition of the immunological memory in response to antigen stimulation, especially in $\mathrm{CD} 8^{+}$ T-cells.

In these previous patients, susceptibility to infections was not ameliorated, probably because of the lack of reversion in granulocytes. By contrast, as with the three revertant patients with gastrointestinal manifestations, the latest case of LAD-1 in a patient, who was presumably a revertant patient because of the presence of minimal CD $18^{+}$fraction in circulating $\mathrm{CD} 8^{+} \mathrm{T}$-cells, was also affected with severe colitis, which was endoscopically compatible with Crohn's disease (76). The inflammatory response at barrier sites such as the oral mucosa and probably in the skin and gastrointestinal tract in LAD-1 may be caused by infections because of relative tissue neutropenia and by a defect in the phagocytosis of apoptotic neutrophils by tissue macrophages (i.e., efferocytosis), which acts as signal to downregulate IL-23 and IL-17 responses (77). However, the clinical impact of the presence of CD18-expressing CD8+ T-cells regarding the gastrointestinal inflammatory response remains to be clarified.

\section{XLP-1}

$\mathrm{X}$-linked lymphoproliferative disease type 1 (XLP-1) is caused by loss-of-function mutations in SH2D1A, which encodes SLAMassociated protein (SAP). Patients with XLP-1 are highly susceptible to Epstein-Barr virus (EBV) infection because of the impaired activation and cytotoxicity of $\mathrm{CD} 8^{+} \mathrm{T}$-cells. They also develop hypogammaglobulinemia because of impaired $\mathrm{CD}^{+}{ }^{+} \mathrm{T}$-cell function $(78,79)$. In the first study of somatic reversion in XLP-1, eight patients represented a small fraction of $\mathrm{SAP}^{+}$revertant cells in $\mathrm{CD}^{+} \mathrm{T}$-cells, except for one patient who also presented with $\mathrm{SAP}^{+}$fraction in NK cells (78). Most revertant $\mathrm{CD}^{+} \mathrm{T}$-cells lay in the $\mathrm{CD}^{+} 5 \mathrm{RA}^{-} \mathrm{CCR} 7^{-}$effector memory $\mathrm{T}$-cell compartment and maintained a stable number over decades. In addition, $\mathrm{SAP}^{+}$revertant $\mathrm{CD} 8^{+} \mathrm{T}$-cells showed more proliferation than did the SAP-deficient counterpart and exhibited functional recovery in response to EBV-specific stimulus. As an alternative, in the latest Japanese nationwide survey of XLP-1, three of 18 patients, who were alive at the time of this study, had a longer survival without HSCT, despite having a history of EBV infection (79). A remarkable finding is that all three patients had $3 \%$ to $7 \%$ of the $\mathrm{SAP}^{+}$fraction in $\mathrm{CD}^{+} \mathrm{T}$-cells, and one patient had a smaller fraction of $\mathrm{SAP}^{+}$cells in $\mathrm{CD}^{+} \mathrm{T}$ cells. SAP ${ }^{+} \mathrm{CD}^{+} \mathrm{T}$-cells mostly lay in the effector memory $\mathrm{T}$-cell population and showed proliferation and functional recovery in response to EBV-specific stimulus, compatible to those of healthy controls. In addition, in the patient who harbored revertant $\mathrm{SAP}^{+}$cells in the $\mathrm{CD}^{+}$T-cell population, intracellular IL-10 expression and inducible costimulatory expression were predominantly observed in the revertant $\mathrm{SAP}^{+}$ $\mathrm{CD}^{+}{ }^{+} \mathrm{T}$-cells. This finding suggested that the reversion event conferred partial reconstitution of humoral immunity in this patient. The findings in these studies collectively suggested that a reversion mutation provides the ability for proliferation and the acquisition of effector function for revertant $\mathrm{CD}^{+} \mathrm{T}$-cells in response to $\mathrm{B}$-cells (i.e., the reservoir of $\mathrm{EBV}$ ) and eventually leads to expansion of revertant T-cells in correlation with EBV infection. The fact that a relatively small fraction of revertant cells modified the fatal clinical phenotype of XLP-1 suggested that gene therapy may potentially be an effective strategy for XLP-1.

\section{DOCK8 Deficiency}

Dedicator of cytokinesis 8 (DOCK8) is a guanin nucleotide exchange factor for the Rho-GTPase CDC42, turning it into the active, GTP-bound form. GTPase activation induces dynamic actin cytoskeleton rearrangement, leading to immunological synapse formation, migration, adhesion, and cytolytic granule release. DOCK8 also exhibits an actinindependent function, including the regulation of STAT3 phosphorylation and nuclear translocation. Hence, DOCK8 deficiency impacts innate and adaptive immune responses (80).

Of note, somatic reversions occur in $13 \%$ to $50 \%$ of patients with DOCK8 deficiency $(81,82)$. The high frequency of somatic reversions may reflect the DOCK 8 gene's location within a recombination hotspot that is characterized by many subtelomeric repetitive sequences (81). Reversion is detected more frequently in T-cells, especially in a high proportion of $\mathrm{CD}^{+} \mathrm{T}$-cells, rather than in NK or B-cells, but it is not detected in monocytes $(81,82)$. Revertant $\mathrm{T}$ - and B-cells exhibit expansion in vitro and in vivo and restore $\mathrm{CD} 8^{+} \mathrm{T}$-cell cytotoxicity, $\mathrm{CD} 4^{+} \mathrm{T}$-cell cytokine production, and memory B-cell generation (82). These findings indicate that DOCK8 somewhat exerts a proliferative and survival advantage in numerous lymphoid lineages and has a key role in many fundamental aspects of lymphocyte biology. DOCK8-expressing cells are predominantly enriched in the memory compartment of $\mathrm{CD}^{+}{ }^{+} \mathrm{T}$-cells and $\mathrm{B}$-cells rather than in the corresponding naïve compartment. By contrast, the difference in the proportions of DOCK8-expressing cells in the $\mathrm{CD}^{+} \mathrm{T}$-cell population was not as significant as in $\mathrm{CD} 4^{+} \mathrm{T}$-cells and B-cells $(81,82)$. This finding reflects a possible differential role of DOCK8 among each lymphoid lineage and in $\mathrm{CD} 4^{+}$and $\mathrm{CD} 8^{+}$ T-cell differentiation. Based on a clinical perspective, the increase in revertant cells can delay the progression of the disease, but do not necessarily reconstitute the whole clinical phenotype and do not abrogate the need for HSCT $(81,83-85)$. By contrast, the three patients reported by Pillay et al. exhibited restored protein expression and spontaneous improvement in the clinical 
phenotype (82). These findings from these patients provide evidence that gene therapy is a promising prospect for treating DOCK8 deficiency.

\section{CARD11 Deficiency}

In 2015, the first case of somatic reversion in caspase recruitment domain-containing protein 11 (CARD11) deficiency was reported (86). The patient was one of two Turkish siblings who were born to consanguineous parents. She had postnatally acquired cytomegalovirus infection and presented with the OS-like phenotype, which included erythroderma and lymphadenopathy. She carried a homozygous germline nonsense mutation (c.450C >A) in the coiled-coil domain in the CARD11 gene, which impaired NF$\mathrm{kB}$ signaling and IL-2 production. A somatic second-site mutation (c.449G $>$ T) was detected in the same codon, which restored protein expression, thereby leading to a partial functional restoration in a subset of T-cells. The revertant cells were mostly in tissueinfiltrating $\mathrm{CD}^{+}$and $\mathrm{CD}^{+}$T-cells, but not in granulocytes and fibroblasts, with a highly restricted $\mathrm{T}$-cell repertoire. This finding indicated that reversion may occur before CD4/CD8 lineage commitment in progenitor T-cells. As demonstrated in mouse studies, CARD11 is also essential for the thymic development of FoxP $^{+}$regulatory $\mathrm{T}$-cells, which significantly contributes to peripheral tolerance of T-cells $(87,88)$. These siblings indeed had a lack of regulatory T-cells in the peripheral blood or in lymph node biopsy. Along with the selective advantage of virus-specific revertant $\mathrm{T}$-cells in response to the persistent stimuli by chronic cytomegalovirus infection, the lack of regulatory T-cells may also have a causative role in the development of the OS-like features.

\section{ARPC1B Deficiency}

Actin-related protein $2 / 3$ complex subunit $1 \mathrm{~B}$ (ARPC1B) is a component of the actin-related protein $2 / 3$ complex, which interacts with WASp to induce actin polymerization and generate new branched actin filament networks in the context of cell migration, endocytosis, vesicular trafficking, and cytokinesis (89). ARPC1B exerts a regulatory role for the assembly and maintenance of the actin-related protein $2 / 3$ complex, and its disruption results in morphological, functional, numerical aberrations in platelets, defect in neutrophil motility and chemotaxis, and functional deficiency in T-cells and NK cells (89-93). In 2017, somatic reversion in ARPC1B deficiency was first reported in two patients from unrelated families (89). In these patients, somatic reversion restored ARPC1B protein expression and was associated with a restricted TCR repertoire. One patient harbored revertant cells within the $\mathrm{CD}^{+} \mathrm{T}$-cell compartment, but not in $\mathrm{CD}^{+} \mathrm{T}$-cells and B-cells. The other patient harbored revertant cells in the $\mathrm{CD} 8^{+} \mathrm{T}$-cell and $\mathrm{NK}$ cell compartments. In addition, $\mathrm{ARPC} \mathrm{B}^{+}$revertant $\mathrm{CD}^{+} \mathrm{T}$-cells displayed an improvement in $\mathrm{T}$-cell migration. These findings suggested that reversion mutations in $A R P C 1 B$ provide a preferential advantage in $\mathrm{CD}^{+}$cytotoxic T-cells and NK cells, which is consistent with the fact that the absence of ARPC1B disrupts the proliferation capacity of cytotoxic T-cells (93). Furthermore, revertant CD8 ${ }^{+} \mathrm{T}$ cells were only enriched in effector memory T-cells, $\mathrm{T}$ effector memory- $\mathrm{RA}^{+}$cells, and $\mathrm{T}_{\mathrm{SCM}}$, but not in naïve and central memory T-cells. This finding indicated that part of the selective pressure may have occurred on antigen stimulations, thereby leading to the acquisition of the immunological memory. Neither patient in the study seemed to have an improvement in their clinical phenotype and one of the patients underwent HSCT due to recurrent infections and refractory autoimmune/ autoinflammatory manifestations. The restoration of ARPC1B expression may partially reconstitute $\mathrm{T}$-cell function and proliferation; however, more observations are required to assess whether genetic reconstitution provides the clinical improvement in ARPC1B deficiency.

\section{MYSM1 Deficiency}

Myb-like, SWIRM, and MPN domains 1 (MYSM1) is a histone deubiquitinase that specifically deubiquitinates the K119monoubiquitinated form of histone $2 \mathrm{~A}$, a chromatin marker of gene transcription silencing. MYSM1 reverses the transcription repression of genes that are involved in hematopoietic stem cell homeostasis, hematopoiesis, and lymphocyte differentiation (94). Spontaneous in vivo reversion to normal was recently reported in a male patient with MYSM1 deficiency who harbored a missense mutation (c.1967A>G) that affected the stability of the protein and damaged histone deubiquitinase activity (94). He presented with a complete lack of B-cells, T-cell lymphopenia, bone marrow failure, and developmental abnormalities. During the course of his treatment, he showed spontaneous improvement in the number of lymphoid and myeloid lineages. Analysis of bone marrow mononuclear cells revealed the complete restoration of B-cell development. Circulating B-cells exhibited polyclonal pattern of B-cell receptor IgM and IgG repertoire. A surprising finding was that a genetic reversion to normal was detected in virtually all hematopoietic stem cells (HSCs), and subsequently detected in approximately $100 \%$ of circulating B-cells, NK cells, and monocytes, and in $63.5 \%$ of circulating T-cells. These findings suggested that the reversion event may have provided a selective advantage for these cells in vivo and completely corrected immunological abnormalities and bone marrow failure in this patient. This observation suggests that clinical application of gene therapy will be effective for immunodeficiency and bone marrow failure in patients with MYSM1 deficiency.

\section{WHIM Syndrome}

Warts, hypogammaglobulinemia, infections, and myelokathexis (WHIM) syndrome is usually caused by a gain-of-function mutation in the CXCR4 gene, which is in chromosome 2. CXCR4 signaling is a suppressive modulator of HSC and neutrophil migration from bone marrow. Its gain-of-function mutation results in myelokathexis, which is a characteristic of this disorder. In addition, the CXCR4 gain-of-function mutation may cause a multisystem and combined immunodeficiency disease because of its broad expression in hematopoietic and nonhematopoietic cell types (95). A female patient with WHIM syndrome, designated as WHIM-09, experienced a spontaneous phenotypical remission (96). In this patient, chromothripsis, a complex genetic process characterized by scattering, rearrangement, inversion and deletion of genomic element on one or a few chromosomes (97), affected one copy of chromosome 2 and deleted 164 genes, including the mutated copy of CXCR4, probably in a single HSC from the 
patient. This event conferred to the modified HSC a strong selective advantage over germline mutated cells and corrected the defects in the myeloid and erythroid lineage. By contrast, the lymphoid lineage and epithelial cells were not affected by the reversion event. Therefore, the patient had a somatic mosaic of WHIM cells and reverted non-WHIM cells. The patient has been healthy for at least 20 years since the estimated time point of the reversion event. These findings suggest that the adaptation of genome editing technology to inactivate the mutant CXCR4 allele in autologous HSC is a potential curative strategy for WHIM syndrome.

\section{GATA2 Deficiency}

GATA-binding protein-2 (GATA2) is a transcription factor that is involved in the development of HSCs and is essential for definitive hematopoiesis. Heterozygous mutations in GATA2 results in GATA2 haploinsufficiency and causes qualitative impairment in HSC function. GATA2 deficiency is characterized by various hematopoietic and nonhematopoietic features such as multilineage cytopenias (especially monocytopenia and B-cell and NK cell lymphopenia), hematologic malignancies, immunodeficiency, pulmonary alveolar proteinosis, lymphedema, and sensorineural hearing loss $(98,99)$. The first somatic revertant case of GATA2 deficiency was revealed by the diagnosis of a man's two affected sons who presented with the typical phenotype (98). They harbored a heterozygous mutation in GATA2 (c.216C >A; p.Y72*), which caused a premature stop codon and loss of the two DNA-binding zinc fingers and the nuclear localized signal. By contrast, their father was asymptomatic and displayed normal immunophenotyping. A surprising finding was that he harbored the pathogenic mutation, which was identical with that of his sons, in sperm and skin fibroblasts. However, $93 \%$ of leukocytes carried the silent somatic mutation (c.216C > T; p.Y72Y), which indicated somatic reversion. Sorted monocytes, T-cells, B-cells, and NK cells carried this silent somatic variant in heterozygosity, which indicated that somatic reversion may occur at the HSC stage. The patient remained asymptomatic with no hematopoietic or nonhematopoietic manifestations at the point of time in this study when he was 61 years old, despite the fact that he did not carry the silent somatic variant in the nonhematopoietic lineage. This finding indicates that the restoration of hematopoietic cells is sufficient for preventing the occurrence of hematopoietic and nonhematopoietic manifestations in GATA2 deficiency. These observations suggest the potential advantage of gene therapy. However, more observations are necessary for understanding the full details of somatic reversion in GATA2 deficiency.

\section{SAMD9/SAMD9L Syndrome}

Germline mutations in sterile alpha motif domain protein 9 (SAMD9) and its paralogue SAMD9-like (SAMD9L), which are located in tandem on chromosome $7 \mathrm{q} 21$, are associated with human syndrome with a propensity for bone marrow failure and myelodysplastic syndrome (MDS) with monosomy 7 and $7 \mathrm{q}$ deletion (100, 101). SAMD9 and SAMD9L gain-of-function mutations represent a strong growth-suppressive effect because of the defective endosomal turnover of cytokine receptors such as the epidermal growth factor receptor (100). Somatic reversion events, which remove the mutant SAMD9 and SAMD9L allele, occur via monosomy 7 , chromosome arm 7q deletion, secondsite loss-of-function mutation, and CN-LOH (102-110). Cells that lose the mutant allele may gain a proliferative advantage, relative to the growth restriction imposed in mutation-carrying cells, and thereby result in reversion mosaicism. Any somatic reversion event may be temporarily beneficial for hematopoiesis; however, the loss of the germline mutated copy via monosomy 7 and $7 q$ deletion results in haploinsufficiency $(3,100,108)$. In fact, in an original case series of myelodysplasia, infection, restriction of growth, adrenal hypoplasia, genital phenotypes, enteropathy syndrome, which was initially recognized as a disease caused by SAMD9 gain-of-function mutations, two of 11 patients developed myelodysplastic syndrome (MDS) with monosomy 7 (102). Several additional cases have subsequently been reported and affected patients have a propensity to develop MDS/acute myeloid leukemia with monosomy 7 and 7q deletion $(102,106$, $107,109)$. Like patients with SAMD9 mutations, patients with $S A M D 9 L$ gain-of-function mutations are also predisposed to the development of MDS/acute myeloid leukemia with monosomy 7 and $7 \mathrm{q}$ deletion $(108,109)$. CN-LOH and second-site loss-offunction mutation can apparently rescue the hematopoietic defect without MDS/acute myeloid leukemia predisposition in both disorders (100, 103-105, 107-110).

In the recent investigation of pediatric MDS cohort, $8 \%$ of the consecutively diagnosed patients harbored germline SAMD9/ SAMD9L mutations (101). Of the patients with SAMD9/ SAMD9L mutations, $61 \%$ underwent somatic reversion, of whom $51 \%$ had benign (CN-LOH or second-site mutation) and $95 \%$ had maladaptive nature (monosomy 7 and $7 q$ deletion). Furthermore, bone marrow single-cell sequencing revealed multiple competing reversions in individual patients. As shown in the study, somatic reversion in SAMD9/SAMD9L syndrome is highly prevalent and diverse, and changes in clonal diversity may modify clinical outcomes of the patients.

\section{DISCUSSION}

Over the past decades, observations of somatic reversion in PIDs have provided significant insights into the function of genes in different cell types, the frequency and mechanism of genetic changes, and clinical consequences because of the presence of revertant cells. These observations have yielded the notion that reversion events provide a wide-spectrum of molecular and clinical effects in PID patients. In fact, the molecular mechanisms that restore gene expression and function vary from single nucleotide substitutions to large deletions or insertions. Moreover, chromosomal structural change, as seen in WHIM syndrome and SAMD9/SAMD9L syndrome, contributes to complete gene abrogation in PIDs caused by gain-of-function mutations $(96,102-110)$.

The increased number of reversions in PIDs suggests that reversion mutations may occur much more frequently than previously believed rather than being a significantly rare event that occurs in distinctive situations. The relatively high occurrence of reversion is substantiated by the fact that 
independent reversions can occur in respective siblings $(30,64$, 79) and in respective cell lineages (81). In addition, reversion mutations have been also discovered in myeloid and erythroid lineages and in nonhematopoietic cells, whereas lymphoid lineages are most frequently affected $(65,94,96,98,105,106)$ (Table 3). Together with these observations, reversion mutations can occur frequently in various cell types and differentiation stages and can be detected when affected cells acquire a proliferative advantage, which can be determined by, at least, the following factors: the type of cell, the timing of reversion, the lifespan of revertant cells, the nature of mutant genes, and extrinsic factors such as persistent antigen stimulations (3, 5, 78). Based on this perspective, even when various cell lineages share the same reversion, identical reversions may occur independently at more differentiated stages rather than from a single less-differentiated common progenitor.

Reversion mutations frequently occur in some PIDs, although susceptible genes and locations may not be random. For example, distinctive sequences in WAS have been implicated in reversion mutation by means of DNA slippage mechanism or hairpin loop formation (29-32). In addition, the homologous sequence of $I K B K G$ (i.e., pseudogene) and subtelomeric repetitive sequences in the DOCK 8 locus may have contributed to the recombination-mediated somatic repair $(70,81,82)$. (Table 3). Loss-of-function mutations in genes that are involved in genomic stability such as BLM, LIG4, FANCA,
FANCC, FANCD2, and presumably WAS may be associated with a high incidence of reversion mutations (3, 51-53). Gene variation analysis, used to evaluate the mutation frequency of PID genes in which reversion events have or have not been described, has revealed that genetic variation is significantly greater for revertant genes than for nonrevertant or control genes, especially in coding sequences (18). The study also demonstrated that the presence of $\mathrm{CpG}$ islands was more frequent in revertant PID genes than in nonrevertant genes; however, other factors such as local chromatin structure and accessibility for DNA repair may influence mutation frequency (18). These intrinsic gene properties in collaborating with longterm management using mutagenic agents and prompt cell turnover due to chronic infections and inflammation (which may induce DNA polymerase mistakes) may be involved in the high incidence of reversion mutations.

As observed in previous reversion cases in PIDs, reversion mutations are predominantly found in T-cell populations (Tables 1-3). This fact may reflect the consequence of the selective occurrence of reversion mutations in T-cell lineage. Extensive intrathymic cell division and the existence of selfrenewing, long-persisting memory $\mathrm{T}$-cells-that is, $\mathrm{T}_{\mathrm{SCM}}$-may account for the selective reversion detection in T-cells $(3,89$, 111). As an alternative, reversion mutations may occur in various cell lineages with the same probability or in less-differentiated hematopoietic progenitor cells. In this scenario, selective

TABLE 3 | Other PIDs in which somatic reversion has been detected.

\begin{tabular}{|c|c|c|c|}
\hline Disease & Type of reversion & Revertant cell & Reference \\
\hline ADA deficiency & $\begin{array}{l}\text { Back mutation } \\
\text { Second-site mutation }\end{array}$ & $\mathrm{CD}^{+} \mathrm{T}, \mathrm{CD}^{+} \mathrm{T}, \mathrm{B}, \mathrm{NK}$ & $(6,54-58)$ \\
\hline RAG1 deficiency & $\begin{array}{l}\text { Back mutation } \\
\text { Second-site mutation }\end{array}$ & $\mathrm{CD}^{+}{ }^{+} \mathrm{T}, \mathrm{CD}^{+} \mathrm{T}$ & $(14,15)$ \\
\hline 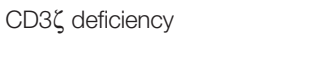 & $\begin{array}{l}\text { Back mutation } \\
\text { Second-site mutation }\end{array}$ & $\mathrm{CD}^{+}{ }^{+} \mathrm{T}, \mathrm{CD}^{+} \mathrm{T}, \mathrm{NK}$ & $(16-19)$ \\
\hline$X L-E D A-I D$ & $\begin{array}{l}\text { Loss of the duplicated region } \\
\text { Back mutation }\end{array}$ & $\mathrm{CD}^{+}{ }^{+} \mathrm{T}, \mathrm{CD}^{+} \mathrm{T}, \mathrm{B}, \mathrm{NK}$ & $(69-71)$ \\
\hline LAD-1 & $\begin{array}{l}\text { Back mutation } \\
\text { Site-specific substitution } \\
\text { Second-site mutation }\end{array}$ & $\mathrm{CD}^{+} \mathrm{T}, \mathrm{NK}$ & $(74-76)$ \\
\hline XLP-1 & $\begin{array}{l}\text { Back mutation } \\
\text { Site-specific substitution }\end{array}$ & $\mathrm{CD}^{+}{ }^{\mathrm{T}} \mathrm{T}, \mathrm{CD} 8^{+} \mathrm{T}, \mathrm{NK}$ & $(78,79)$ \\
\hline DOCK8 deficiency & $\begin{array}{l}\text { Back mutation } \\
\text { Second-site mutation } \\
\mathrm{CN}-\mathrm{LOH} \\
\text { Intragenic recombination } \\
\text { Loss of the duplication/deletion mutation }\end{array}$ & $\mathrm{CD}^{+}{ }^{+} \mathrm{T}, \mathrm{CD}^{+} \mathrm{T}, \mathrm{B}, \mathrm{NK}$ & $(81-85)$ \\
\hline JAK3 deficiency & Back mutation & $\mathrm{CD}^{+} \mathrm{T}, \mathrm{CD} 8^{+} \mathrm{T}$ & $(64)$ \\
\hline DNA ligase IV deficiency & Intragenic recombination & $\mathrm{T}, \mathrm{NK}$, granulocytes, oral mucosa & (65) \\
\hline CARD11 deficiency & Second-site mutation & $\mathrm{CD}^{+} \mathrm{T}, \mathrm{CD} 8^{+} \mathrm{T}$ & (86) \\
\hline ARPC1B deficiency & Back mutation & $\mathrm{CD}^{+} \mathrm{T}, \mathrm{NK}$ & (89) \\
\hline MYSM1 deficiency & Back mutation & $\mathrm{T}, \mathrm{B}, \mathrm{NK}$, monocytes & $(94)$ \\
\hline WHIM syndrome & Chromothripsis & myeloid and erythroid lineage & $(96)$ \\
\hline GATA2 deficiency & Site-specific substitution & $\mathrm{T}, \mathrm{B}, \mathrm{NK}$, monocytes & (98) \\
\hline SAMD9/SAMD9L syndrome & $\begin{array}{l}\text { Monosomy } 7 \\
\text { Deletion of } 7 q \\
\text { Second-site mutation } \\
\text { CN-LOH }\end{array}$ & BM and PB cells (including myeloid and lymphoid lineage) & $(102-110)$ \\
\hline
\end{tabular}

PID, primary immunodeficiency disease; NK, natural killer; CN-LOH, copy-neutral loss of heterozygosity; BM, bone marrow; PB, peripheral blood. 
proliferation of revertant T-cells may be caused by any or all of the following factors: homeostatic expansion on the background of T-cell lymphopenia, intrinsic gene function for T-cell proliferation, and persistent antigen-specific responses (3) (Figures 2A, B). In the context of the basic pathology with bone marrow failure or neutropenia-that is, the function of an affected gene being equally essential for some or all hematopoietic lineages-reversion mutations have been detected in cells other than lymphoid lineages, as observed in SAMD9/SAMD9L syndrome, MYSM1 deficiency, WHIM syndrome, GATA2 deficiency, and Fanconi anemia (94, 96, 98, 105, 106, 112) (Table 3 and Figure 2C). For the aforementioned reasons, reversion mutations may be predominant in $\mathrm{T}$ cell populations.

The detection of somatic mosaicism by using conventional standard Sanger sequencing is challenging because the variant peak can be misinterpreted as background noise on the chromatogram when revertant cells constitute a minimal fraction (2). Highly sensitive and efficient molecular technologies such as deep sequencing technologies and quantitative techniques such as droplet digital PCR allow the detection and quantification of low-frequency mosaicism (1-3, 19, 113). These technologies can permit the efficient and accurate sequential observation of mosaicism, which will reveal important matters such as the relationship between spontaneous mosaicism oscillation and the clinical phenotype, the effect of alternative treatment on mosaicism [e.g., ADA deficiency (55-58) and XLEDA-ID (71)], and the therapeutic effect of gene therapy (1). Furthermore, emerging sensitive and innovative methodologies, especially "single-cell" approaches, will facilitate reversion detection and the evaluation of characteristics, behavior, and fate of a revertant cell $(3,113)$.

Owing to overlapping and complicated phenotypes, the diagnosis of PIDs is not necessarily easy. Reversion mutations can modify clinical and immunological phenotypes; therefore, diagnostic delay and underdiagnosis can occur, particularly when the disease intrinsically presents with diverse clinical and immunological features, as seen in XL-EDA-ID (69).

Furthermore, the technical limitations and the nature of the gene may make a genetic diagnosis difficult. For example, transcriptomics is often used as a complementary diagnostic tool if patients remain without a molecular diagnosis after target next-generation sequencing, whole exome sequencing, and whole genome sequencing analysis; however, a molecular diagnosis can be delayed, if revertant wild-type allele is selectively amplified (84). In addition, if most blood cells are revertant cells, a molecular diagnosis can be hampered by the major detection of revertant wild-type alleles. Therefore, genetic

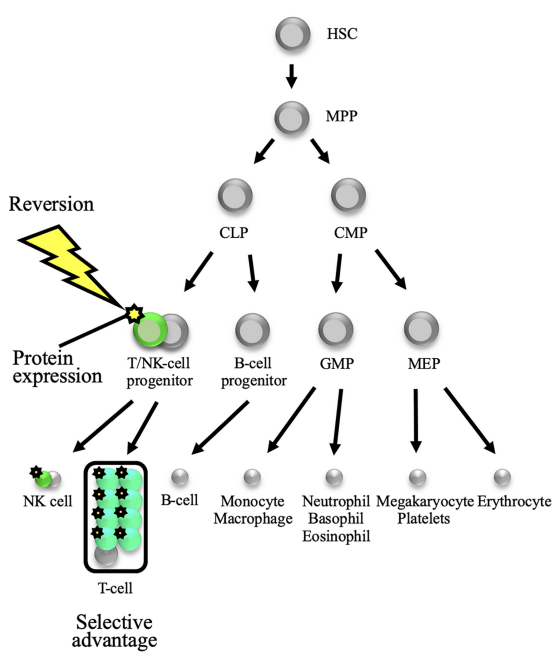

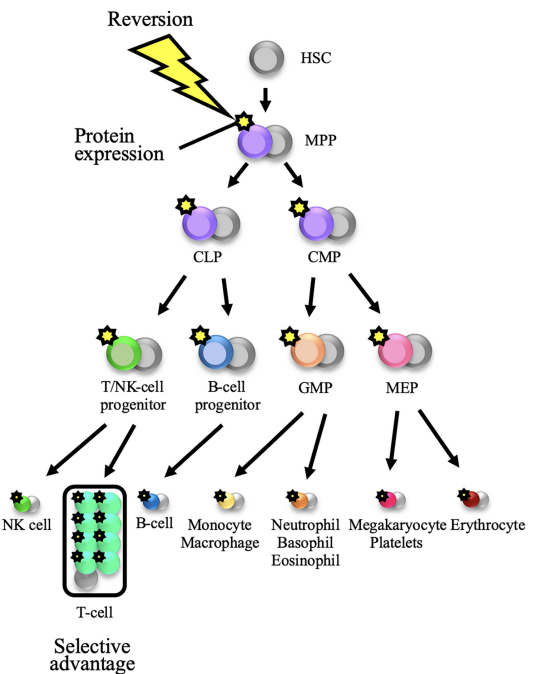

C

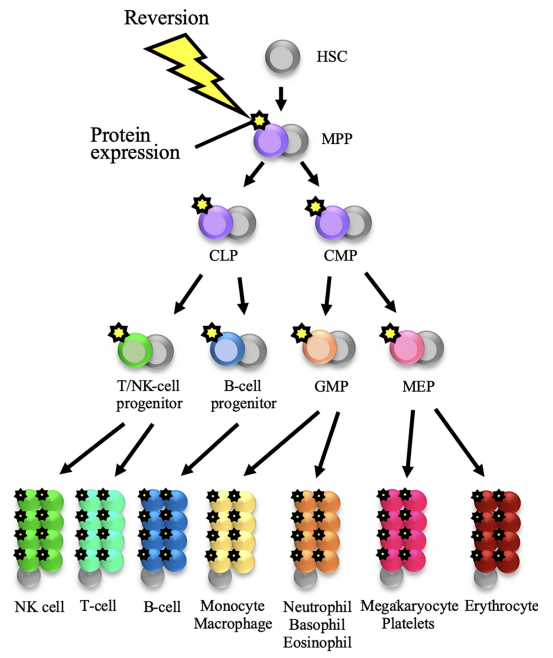

FIGURE 2 | Schematic representations of somatic reversion in the hematopoietic system that eventually results in distinct hematological and immunological reconstitution. (A) A somatic reversion event can occur at a late stage of the hematopoietic hierarchy and provide a selective advantage to a restricted lineage. The diagram shows the occurrence of reversion in a T/NK-cell progenitor. When T-cell lineage selectively exhibits a proliferative advantage, somatic mosaicism will be detected only in the T-cell population. This model is applicable to the reversion mosaicism in the context of severe combined immunodeficiency or a T-cell deficiency. (B) A somatic reversion event can occur in less-differentiated hematopoietic progenitor cells. For example, when reversion mutation occurs in a multipotent progenitor (MPP), cells from all hematopoietic lineages can theoretically harbor the same reversion mutation. However, when the T-cell lineage selectively represents a proliferative advantage, somatic mosaicism will seemingly be detected only in the T-cell lineage. This selective advantage may depend on intrinsic gene function for T-cell proliferation and/or persistent antigen-specific responses. In disorders with T-cell lymphopenia such as severe combined immunodeficiency, homeostatic expansion will further provide a positive effect on proliferative advantage over the T-cell lineage. (C) When the germline mutation is deleterious for all hematopoietic lineages (i.e., the function of the affected gene is equally essential for all hematopoietic lineages), the reversion mutation in less-differentiated progenitor cells can reconstitute the whole hematopoietic system. In this scenario, somatic mosaicism can be detected in all compartments. Bone marrow failure disorders may be applicable to this model. HSC, hematopoietic stem cell; CLP, common lymphoid progenitor; CMP, common myeloid progenitor; GMP, granulocyte-monocyte progenitor; MEP, megakaryocyte-erythroid progenitor; NK, natural killer. 
analysis on DNA extracted from a tissue other than peripheral blood such as buccal mucosa cells and, optimally, skin fibroblasts may be advisable, particularly when a concern exists about a PID for which the reversion occurrence is relatively high such as WAS, DOCK8 deficiency, and XL-EDA-ID (3).

In summary, the clinical impact of somatic reversion depends on the type, differentiation, diversity, and number and function of cells in which reversion occurs, intrinsic function of an affected gene, and location of the germline mutation. In the context of the adaptation of gene therapy for PID patients, cells harboring artificial genomic changes should work as expected in vivo. To date, the mechanism of reversion and the function of

\section{REFERENCES}

1. Mensa-Vilaró A, Bravo García-Morato M, de la Calle-Martin O, Franco-Jarava C, Martínez-Saavedra MT, González-Granado LI, et al. Unexpected Relevant Role of Gene Mosaicism in Patients With Primary Immunodeficiency Diseases. J Allergy Clin Immunol (2019) 143:359-68. doi: 10.1016/j.jaci.2018.09.009

2. Aluri J, Cooper MA. Genetic Mosaicism as a Cause of Inborn Errors of Immunity. J Clin Immunol (2021) 41:718-28. doi: 10.1007/s10875-02101037-z

3. Revy P, Kannengiesser C, Fischer A. Somatic Genetic Rescue in Mendelian Haematopoietic Diseases. Nat Rev Genet (2019) 20:582-98. doi: 10.1038/ s41576-019-0139-x

4. Wada T, Candotti F. Somatic Mosaicism in Primary Immune Deficiencies. Curr Opin Allergy Clin Immunol (2008) 8:510-4. doi: 10.1097/ ACI.0b013e328314b651

5. Kuijpers TW, van Leeuwen EM, Barendregt BH, Klarenbeek P, aan De Kerk DJ, Baars PA, et al. A Reversion of an IL2RG Mutation in Combined Immunodeficiency Providing Competitive Advantage to the Majority of $\mathrm{CD}^{+}$T Cells. Haematologica (2013) 98:1030-8. doi: 10.3324/haematol. 2012.077511

6. Hirschhorn R, Yang DR, Israni A, Huie ML, Ownby DR. Somatic Mosaicism for a Newly Identified Splice-Site Mutation in a Patient With Adenosine Deaminase-Deficient Immunodeficiency and Spontaneous Clinical Recovery. Am J Hum Genet (1994) 55:59-68.

7. Stephan V, Wahn V, Le Deist F, Dirksen U, Broker B, Müller-Fleckenstein I, et al. Atypical X-Linked Severe Combined Immunodeficiency Due to Possible Spontaneous Reversion of the Genetic Defect in T Cells. N Engl J Med (1996) 335:1563-7. doi: 10.1056/NEJM199611213352104

8. Bousso P, Wahn V, Douagi I, Horneff G, Pannetier C, Le Deist F, et al. Diversity, Functionality, and Stability of the T Cell Repertoire Derived In Vivo From a Single Human T Cell Precursor. Proc Natl Acad Sci U S A (2000) 97:274-8. doi: 10.1073/pnas.97.1.274

9. Wada T, Yasui M, Toma T, Nakayama Y, Nishida M, Shimizu M, et al. Detection of T Lymphocytes With a Second-Site Mutation in Skin Lesions of Atypical X-Linked Severe Combined Immunodeficiency Mimicking Omenn Syndrome. Blood (2008) 112:1872-5. doi: 10.1182/blood-2008-04-149708

10. Speckmann C, Pannicke U, Wiech E, Schwarz K, Fisch P, Friedrich W, et al. Clinical and Immunologic Consequences of a Somatic Reversion in a Patient With X-Linked Severe Combined Immunodeficiency. Blood (2008) 112:4090-7. doi: 10.1182/blood-2008-04-153361

11. Kawai T, Saito M, Nishikomori R, Yasumi T, Izawa K, Murakami T, et al. Multiple Reversions of an IL2RG Mutation Restore T Cell Function in an XLinked Severe Combined Immunodeficiency Patient. J Clin Immunol (2012) 32:690-7. doi: 10.1007/s10875-012-9684-1

12. Hsu AP, Pittaluga S, Martinez B, Rump AP, Raffeld M, Uzel G, et al. IL2RG Reversion Event in a Common Lymphoid Progenitor Leads to Delayed Diagnosis and Milder Phenotype. J Clin Immunol (2015) 35:449-53. doi: 10.1007/s10875-015-0174-0

13. Okuno Y, Hoshino A, Muramatsu H, Kawashima N, Wang X, Yoshida K, et al. Late-Onset Combined Immunodeficiency With a Novel IL2RG revertant cells have been elucidated by means of emerging technologies, even in genes and in cell types in which reversion events have not been described. In the future, further technological evolutions will enable scientists to generate new perspectives for reversion mosaicism in PIDs.

\section{AUTHOR CONTRIBUTIONS}

HM and TW wrote and critically revised the manuscript. All authors contributed to the article and approved the submitted version.

Mutation and Probable Revertant Somatic Mosaicism. J Clin Immunol (2015) 35:610-4. doi: 10.1007/s10875-015-0202-0

14. Wada T, Toma T, Okamoto H, Kasahara Y, Koizumi S, Agematsu K, et al. Oligoclonal Expansion of T Lymphocytes With Multiple Second-Site Mutations Leads to Omenn Syndrome in a Patient With RAG1-Deficient Severe Combined Immunodeficiency. Blood (2005) 106:2099-101. doi: 10.1182/blood-2005-03-0936

15. Crestani E, Choo S, Frugoni F, Lee YN, Richards S, Smart J, et al. RAG1 Reversion Mosaicism in a Patient With Omenn Syndrome. J Clin Immunol (2014) 34:551-4. doi: 10.1007/s10875-014-0051-2

16. Rieux-Laucat F, Hivroz C, Lim A, Mateo V, Pellier I, Selz F, et al. Inherited and Somatic CD3 $\zeta$ Mutations in a Patient With T-Cell Deficiency. N Engl J Med (2006) 354:1913-21. doi: 10.1056/NEJMoa053750

17. Marin AV, Jiménez-Reinoso A, Briones AC, Muñoz-Ruiz M, Aydogmus C, Pasick LJ, et al. Primary T-Cell Immunodeficiency With Functional Revertant Somatic Mosaicism in CD247. J Allergy Clin Immunol (2017) 139:347-49.e8. doi: 10.1016/j.jaci.2016.06.020

18. Blázquez-Moreno A, Pérez-Portilla A, Agúndez-Llaca M, Dukovska D, Valés-Gómez M, Aydogmus C, et al. Analysis of the Recovery of CD247 Expression in a PID Patient: Insights Into the Spontaneous Repair of Defective Genes. Blood (2017) 130:1205-8. doi: 10.1182/blood-2017-01762864

19. Kaiser FMP, Reisli I, Pico-Knijnenburg I, Langerak AW, Kavelaars FG, Artac $\mathrm{H}$, et al. Protein Functionality as a Potential Bottleneck for Somatic Revertant Variants. J Allergy Clin Immunol (2021) 147:391-3.e8. doi: 10.1016/j.jaci.2020.04.045

20. Ariga T, Yamada M, Sakiyama Y, Tatsuzawa O. A Case of Wiskott-Aldrich Syndrome With Dual Mutations in Exon 10 of the WASP Gene: An Additional De Novo One-Base Insertion, Which Restores Frame Shift Due to an Inherent One-Base Deletion, Detected in the Major Population of the Patient's Peripheral Blood Lymphocytes. Blood (1998) 92:699-701. doi: 10.1182/blood.V92.2.699

21. Ariga T, Kondoh T, Yamaguchi K, Yamada M, Sasaki S, Nelson DL, et al. Spontaneous In Vivo Reversion of an Inherited Mutation in the WiskottAldrich Syndrome. J Immunol (2001) 166:5245-9. doi: 10.4049/ jimmunol.166.8.5245

22. Stewart DM, Candotti F, Nelson DL. The Phenomenon of Spontaneous Genetic Reversions in the Wiskott-Aldrich Syndrome: A Report of the Workshop of the ESID Genetics Working Party at the XIIth Meeting of the European Society for Immunodeficiencies (ESID). Budapest, Hungary October 4-7, 2006. J Clin Immunol (2007) 27:634-9. doi: 10.1007/s10875007-9121-z

23. Boztug K, Germeshausen M, Avedillo Díez I, Gulacsy V, Diestelhorst J, Ballmaier M, et al. Multiple Independent Second-Site Mutations in Two Siblings With Somatic Mosaicism for Wiskott-Aldrich Syndrome. Clin Genet (2008) 74:68-74. doi: 10.1111/j.1399-0004.2008.01019.x

24. Davis BR, Dicola MJ, Prokopishyn NL, Rosenberg JB, Moratto D, Muul LM, et al. Unprecedented Diversity of Genotypic Revertants in Lymphocytes of a Patient With Wiskott-Aldrich Syndrome. Blood (2008) 111:5064-7. doi: 10.1182/blood-2007-06-095299 
25. Lutskiy MI, Park JY, Remold SK, Remold-O’Donnell E. Evolution of Highly Polymorphic T Cell Populations in Siblings With the Wiskott-Aldrich Syndrome. PLoS One (2008) 3:e3444. doi: 10.1371/journal.pone.0003444

26. Davis BR, Yan Q, Bui JH, Felix K, Moratto D, Muul LM, et al. Somatic Mosaicism in the Wiskott-Aldrich Syndrome: Molecular and Functional Characterization of Genotypic Revertants. Clin Immunol (2010) 135:72-83. doi: 10.1016/j.clim.2009.12.011

27. Trifari S, Scaramuzza S, Catucci M, Ponzoni M, Mollica L, Chiesa R, et al. Revertant T Lymphocytes in a Patient With Wiskott-Aldrich Syndrome: Analysis of Function and Distribution in Lymphoid Organs. J Allergy Clin Immunol (2010) 125:439-48.e8. doi: 10.1016/j.jaci.2009.11.034

28. Xie JW, Zhang ZY, Wu JF, Liu DW, Liu W, Zhao Y, et al. In Vivo Reversion of an Inherited Mutation in a Chinese Patient With Wiskott-Aldrich Syndrome. Hum Immunol (2015) 76:406-13. doi: 10.1016/j.humimm. 2015.04.001

29. Wada T, Schurman SH, Otsu M, Garabedian EK, Ochs HD, Nelson DL, et al. Somatic Mosaicism in Wiskott-Aldrich Syndrome Suggests In Vivo Reversion by a DNA Slippage Mechanism. Proc Natl Acad Sci U S A (2001) 98:8697-702. doi: 10.1073/pnas.151260498

30. Wada T, Konno A, Schurman SH, Garabedian EK, Anderson SM, Kirby M, et al. Second-Site Mutation in the Wiskott-Aldrich Syndrome (WAS) Protein Gene Causes Somatic Mosaicism in Two WAS Siblings. J Clin Invest (2003) 111:1389-97. doi: 10.1172/JCI15485

31. Wada T, Schurman SH, Jagadeesh GJ, Garabedian EK, Nelson DL, Candotti F. Multiple Patients With Revertant Mosaicism in a Single Wiskott-Aldrich Syndrome Family. Blood (2004) 104:1270-2. doi: 10.1182/blood-2004-030846

32. Konno A, Wada T, Schurman SH, Garabedian EK, Kirby M, Anderson SM, et al. Differential Contribution of Wiskott-Aldrich Syndrome Protein to Selective Advantage in T- and B-Cell Lineages. Blood (2004) 103:676-8. doi: 10.1182/blood-2003-05-1739

33. Lutskiy MI, Beardsley DS, Rosen FS, Remold-O'donnell E. Mosaicism of NK Cells in a Patient With Wiskott-Aldrich Syndrome. Blood (2005) 106:28157. doi: 10.1182/blood-2004-12-4724

34. Du W, Kumaki S, Uchiyama T, Yachie A, Looi CY, Kawai S, et al. A SecondSite Mutation in the Initiation Codon of WAS (WASP) Results in Expansion of Subsets of Lymphocytes in an Wiskott-Aldrich Syndrome Patient. Hum Mutat (2006) 27:370-5. doi: 10.1002/humu.20308

35. Humblet-Baron S, Sather B, Anover S, Becker-Herman S, Kasprowicz DJ, Khim S, et al. Wiskott-Aldrich Syndrome Protein Is Required for Regulatory T Cell Homeostasis. J Clin Invest (2007) 117:407-18. doi: 10.1172/JCI29539

36. Boztug K, Baumann U, Ballmaier M, Webster D, Sandrock I, Jacobs R, et al. Large Granular Lymphocyte Proliferation and Revertant Mosaicism: Two Rare Events in a Wiskott-Aldrich Syndrome Patient. Haematologica (2007) 92:e43-5. doi: 10.3324/haematol.11222

37. Fischer A, Hacein-Bey-Abina S. Gene Therapy for Severe Combined Immunodeficiencies and Beyond. J Exp Med (2020) 217:e20190607. doi: $10.1084 /$ jem. 20190607

38. Aiuti A, Biasco L, Scaramuzza S, Ferrua F, Cicalese MP, Baricordi C, et al. Lentivirus-Based Gene Therapy of Hematopoietic Stem Cells in WiskottAldrich Syndrome. Science (2013) 341:1233151. doi: 10.1126/ science. 1233151

39. Davis BR, Candotti F. Revertant Somatic Mosaicism in the Wiskott-Aldrich Syndrome. Immunol Res (2009) 44:127-31. doi: 10.1007/s12026-008-8091-4

40. Candotti F. Clinical Manifestations and Pathophysiological Mechanisms of the Wiskott-Aldrich Syndrome. J Clin Immunol (2018) 38:13-27. doi: 10.1007/s10875-017-0453-z

41. Mastio J, Saeed MB, Wurzer H, Krecke M, Westerberg LS, Thomas C. Higher Incidence of B Cell Malignancies in Primary Immunodeficiencies: A Combination of Intrinsic Genomic Instability and Exocytosis Defects at the Immunological Synapse. Front Immunol (2020) 11:581119. doi: 10.3389/ fimmu.2020.581119

42. Sullivan KE, Stiehm ER. Stiehm's Immune Deficiencies: Inborn Errors of Immunity. 2nd ed. New York: Academic Press (2020). p. 243-5.

43. Jin Y, Mazza C, Christie JR, Giliani S, Fiorini M, Mella P, et al. Mutations of the Wiskott-Aldrich Syndrome Protein (WASP): Hotspots, Effect on Transcription, and Translation and Phenotype/Genotype Correlation. Blood (2004) 104:4010-9. doi: 10.1182/blood-2003-05-159249
44. Pasmooij AM, Pas HH, Bolling MC, Jonkman MF. Revertant Mosaicism in Junctional Epidermolysis Bullosa Due to Multiple Correcting Second-Site Mutations in LAMB3. J Clin Invest (2007) 117:1240-8. doi: 10.1172/ JCI30465

45. Symons M, Derry JM, Karlak B, Jiang S, Lemahieu V, Mccormick F, et al. Wiskott-Aldrich Syndrome Protein, a Novel Effector for the GTPase CDC42Hs, Is Implicated in Actin Polymerization. Cell (1996) 84:723-34. doi: 10.1016/s0092-8674(00)81050-8

46. Teitell MA. Alternative Control: What's WASp Doing in the Nucleus? Sci Transl Med (2010) 2:37ps31. doi: 10.1126/scitranslmed.3001336

47. Taylor MD, Sadhukhan S, Kottangada P, Ramgopal A, Sarkar K, D'Silva S, et al. Nuclear Role of WASp in the Pathogenesis of Dysregulated TH1 Immunity in Human Wiskott-Aldrich Syndrome. Sci Transl Med (2010) 2:37ra44. doi: 10.1126/scitranslmed.3000813

48. Sarkar K, Sadhukhan S, Han SS, Vyas YM. Disruption of hSWI/SNF Complexes in T Cells by WAS Mutations Distinguishes X-Linked Thrombocytopenia From Wiskott-Aldrich Syndrome. Blood (2014) 124:3409-19. doi: 10.1182/blood-2014-07-587642

49. Sadhukhan S, Sarkar K, Taylor M, Candotti F, Vyas YM. Nuclear Role of WASp in Gene Transcription Is Uncoupled From Its ARP2/3-Dependent Cytoplasmic Role in Actin Polymerization. J Immunol (2014) 193:150-60. doi: 10.4049/jimmunol.1302923

50. Sarkar K, Sadhukhan S, Han SS, Vyas YM. SUMOylation-Disrupting WAS Mutation Converts WASp From a Transcriptional Activator to a Repressor of NF-kB Response Genes in T Cells. Blood (2015) 126:1670-82. doi: 10.1182/blood-2015-05-646182

51. Sarkar K, Han SS, Wen KK, Ochs HD, Dupré L, Seidman MM, et al. R-Loops Cause Genomic Instability in Wiskott-Aldrich Syndrome T Helper Lymphocytes. J Allergy Clin Immunol (2018) 142:219-34. doi: 10.1016/ j.jaci.2017.11.023

52. Schrank BR, Aparicio T, Li Y, Chang W, Chait BT, Gundersen GG, et al. Nuclear Arp2/3 Drives DNA Break Clustering for Homology-Directed Repair. Nature (2018) 559:61-6. doi: 10.1038/s41586-018-0237-5

53. Wen KK, Han SS, Vyas YM. Wiskott-Aldrich Syndrome Protein Senses Irradiation-Induced DNA Damage to Coordinate the Cell-Protective Golgi Dispersal Response in Human T and B Lymphocytes. J Allergy Clin Immunol (2021) 145:324-34. doi: 10.1016/j.jaci.2019.09.026

54. Hirschhorn R, Yang DR, Puck IM, Huie ML, Jiang CK, Kurlandsky LE. Spontaneous In Vivo Reversion to Normal of an Inherited Mutation in a Patient With Adenosine Deaminase Deficiency. Nat Genet (1996) 13:290-5. doi: 10.1038/ng0796-290

55. Ariga T, Oda N, Yamaguchi K, Kawamura N, Kikuta H, Taniuchi S, et al. TCell Lines From 2 Patients With Adenosine Deaminase (ADA) Deficiency Showed the Restoration of ADA Activity Resulted From the Reversion of an Inherited Mutation. Blood (2001) 97:2896-9. doi: 10.1182/blood.v97.9.2896

56. Arredondo-Vega FX, Santisteban I, Richard E, Bali P, Koleilat M, Loubser M, et al. Adenosine Deaminase Deficiency With Mosaicism for a "Second-Site Suppressor" of a Splicing Mutation: Decline in Revertant T Lymphocytes During Enzyme Replacement Therapy. Blood (2002) 99:1005-13. doi: 10.1182/blood.v99.3.1005

57. Liu P, Santisteban I, Burroughs LM, Ochs HD, Torgerson TR, Hershfield MS, et al. Immunologic Reconstitution During PEG-ADA Therapy in an Unusual Mosaic ADA-Deficient Patient. Clin Immunol (2009) 130:162-74. doi: 10.1016/j.clim.2008.08.026

58. Moncada-Vélez M, Vélez-Ortega A, Orrego J, Santisteban I, Jagadeesh J, Olivares M, et al. Somatic Mosaicism Caused by Monoallelic Reversion of a Mutation in T Cells of a Patient With ADA-SCID and the Effects of Enzyme Replacement Therapy on the Revertant Phenotype. Scand J Immunol (2011) 74:471-81. doi: 10.1111/j.1365-3083.2011.02593.x

59. Biasco L, Scala S, Basso Ricci L, Dionisio F, Baricordi C, Calabria A, et al. In Vivo Tracking of T Cells in Humans Unveils Decade-Long Survival and Activity of Genetically Modified T Memory Stem Cells. Sci Transl Med (2015) 7:273ra13. doi: 10.1126/scitranslmed.3010314

60. Hönig M, Schwarz K. Omenn Syndrome: A Lack of Tolerance on the Background of Deficient Lymphocyte Development and Maturation. Curr Opin Rheumatol (2006) 18:383-8. doi: 10.1097/01.bor.0000231907.50290.6f

61. Kato M, Kimura H, Seki M, Shimada A, Hayashi Y, Morio T, et al. Omenn Syndrome-Review of Several Phenotypes of Omenn Syndrome and RAG1/ 
RAG2 Mutations in Japan. Allergol Int (2006) 55:115-9. doi: 10.2332/ allergolint.55.115

62. Pénit C, Lucas B, Vasseur F. Cell Expansion and Growth Arrest Phases During the Transition From Precursor $\left(\mathrm{CD} 4-8^{-}\right)$to Immature $\left(\mathrm{CD}^{+} 8^{+}\right)$ Thymocytes in Normal and Genetically Modified Mice. J Immunol (1995) 154:5103-13.

63. Roberts JL, Lauritsen JP, Cooney M, Parrott RE, Sajaroff EO, Win CM, et al. $\mathrm{T}-\mathrm{B}^{+} \mathrm{NK}^{+}$Severe Combined Immunodeficiency Caused by Complete Deficiency of the $\mathrm{CD} 3 \zeta$ Subunit of the T-Cell Antigen Receptor Complex. Blood (2007) 109:3198-206. doi: 10.1182/blood-2006-08-043166

64. Ban SA, Salzer E, Eibl MM, Linder A, Geier CB, Santos-Valente E, et al. Combined Immunodeficiency Evolving Into Predominant $\mathrm{CD}^{+}$ Lymphopenia Caused by Somatic Chimerism in JAK3. J Clin Immunol (2014) 34:941-53. doi: 10.1007/s10875-014-0088-2

65. Jiang J, Tang W, An Y, Tang M, Wu J, Qin T, et al. Molecular and Immunological Characterization of DNA Ligase IV Deficiency. Clin Immunol (2016) 163:75-83. doi: 10.1016/j.clim.2015.12.016

66. Bayer DK, Martinez CA, Sorte HS, Forbes LR, Demmler-Harrison GJ, Hanson IC, et al. Vaccine-Associated Varicella and Rubella Infections in Severe Combined Immunodeficiency With Isolated CD4 Lymphocytopenia and Mutations in IL7R Detected by Tandem Whole Exome Sequencing and Chromosomal Microarray. Clin Exp Immunol (2014) 178:459-69. doi: $10.1111 /$ cei.12421

67. Courtois G, Smahi A, Israël A. NEMO/Ikk $\gamma$ : Linking NF-kb to Human Disease. Trends Mol Med (2001) 7:427-30. doi: 10.1016/s1471-4914(01) 02154-2

68. Kawai T, Nishikomori R, Heike T. Diagnosis and Treatment in Anhidrotic Ectodermal Dysplasia With Immunodeficiency. Allergol Int (2012) 61:20717. doi: 10.2332/allergolint.12-RAI-0446

69. Kawai T, Nishikomori R, Izawa K, Murata Y, Tanaka N, Sakai H, et al. Frequent Somatic Mosaicism of NEMO in T Cells of Patients With X-Linked Anhidrotic Ectodermal Dysplasia With Immunodeficiency. Blood (2012) 119:5458-66. doi: 10.1182/blood-2011-05-354167

70. Nishikomori R, Akutagawa H, Maruyama K, Nakata-Hizume M, Ohmori K, Mizuno K, et al. X-Linked Ectodermal Dysplasia and Immunodeficiency Caused by Reversion Mosaicism of NEMO Reveals a Critical Role for NEMO in Human T-Cell Development and/or Survival. Blood (2004) 103:4565-72. doi: 10.1182/blood-2003-10-3655

71. Mizukami T, Obara M, Nishikomori R, Kawai T, Tahara Y, Sameshima N, et al. Successful Treatment With Infliximab for Inflammatory Colitis in a Patient With X-Linked Anhidrotic Ectodermal Dysplasia With Immunodeficiency. J Clin Immunol (2012) 32:39-49. doi: 10.1007/s10875011-9600-0

72. Nenci A, Becker C, Wullaert A, Gareus R, van Loo G, Danese S, et al. Epithelial NEMO Links Innate Immunity to Chronic Intestinal Inflammation. Nature (2007) 446:557-61. doi: 10.1038/nature05698

73. Sullivan KE, Stiehm ER. Stiehm's Immune Deficiencies: Inborn Errors of Immunity. 2nd ed. New York: Academic Press (2020). p. 814-5.

74. Tone Y, Wada T, Shibata F, Toma T, Hashida Y, Kasahara Y, et al. Somatic Revertant Mosaicism in a Patient With Leukocyte Adhesion Deficiency Type 1. Blood (2007) 109:1182-4. doi: 10.1182/blood-2007-08-039057

75. Uzel G, Tng E, Rosenzweig SD, Hsu AP, Shaw JM, Horwitz ME, et al. Reversion Mutations in Patients With Leukocyte Adhesion Deficiency Type1 (LAD-1). Blood (2008) 111:209-18. doi: 10.1182/blood-2007-04-082552

76. Marsili M, Lougaris V, Lucantoni M, Di Marzio D, Baronio M, Vitali M, et al. Successful Anti-TNF- $\alpha$ Treatment in a Girl With LAD-1 Disease and Autoimmune Manifestations. J Clin Immunol (2014) 34:788-91. doi: 10.1007/s10875-014-0086-4

77. Moutsopoulos NM, Zerbe CS, Wild T, Dutzan N, Brenchley L, DiPasquale G, et al. Interleukin-12 and Interleukin-23 Blockade in Leukocyte Adhesion Deficiency Type 1. N Engl J Med (2017) 376:1141-6. doi: 10.1056/ NEJMoa1612197

78. Palendira U, Low C, Bell AI, Ma CS, Abbott RJ, Phan TG, et al. Expansion of Somatically Reverted Memory CD8 ${ }^{+} \mathrm{T}$ Cells in Patients With X-Linked Lymphoproliferative Disease Caused by Selective Pressure From EpsteinBarr Virus. J Exp Med (2012) 209:913-24. doi: 10.1084/jem.20112391

79. Hoshino A, Yang X, Tanita K, Yoshida K, Ono T, Nishida N, et al. Modification of Cellular and Humoral Immunity by Somatically Reverted
T Cells in X-Linked Lymphoproliferative Syndrome Type 1.J Allergy Clin Immunol (2019) 143:421-4.e11. doi: 10.1016/j.jaci.2018.07.044

80. Biggs CM, Keles S, Chatila TA. DOCK8 Deficiency: Insights Into Pathophysiology, Clinical Features and Management. Clin Immunol (2017) 181:75-82. doi: 10.1016/j.clim.2017.06.003

81. Jing H, Zhang Q, Zhang Y, Hill BJ, Dove CG, Gelfand EW, et al. Somatic Reversion in Dedicator of Cytokinesis 8 Immunodeficiency Modulates Disease Phenotype. J Allergy Clin Immunol (2014) 133:1667-75. doi: 10.1016/j.jaci.2014.03.02

82. Pillay BA, Fusaro M, Gray PE, Statham AL, Burnett L, Bezrodnik L, et al. Somatic Reversion of Pathogenic DOCK8 Variants Alters Lymphocyte Differentiation and Function to Effectively Cure DOCK8 Deficiency. J Clin Invest (2021) 131:e142434. doi: 10.1172/JCI142434

83. Kienzler AK, van Schouwenburg PA, Taylor J, Marwah I, Sharma RU, Noakes C, et al. Hypomorphic Function and Somatic Reversion of DOCK8 Cause Combined Immunodeficiency Without Hyper-IgE. Clin Immunol (2016) 163:17-21. doi: 10.1016/j.clim.2015.12.003

84. Hagl B, Spielberger BD, Thoene S, Bonnal S, Mertes C, Winter C, et al. Somatic Alterations Compromised Molecular Diagnosis of DOCK8 HyperIgE Syndrome Caused by a Novel Intronic Splice Site Mutation. Sci Rep (2018) 8:16719. doi: 10.1038/s41598-018-34953-z

85. Saettini F, Fazio G, Moratto D, Galbiati M, Zucchini N, Ippolito D, et al. Case Report: Hypomorphic Function and Somatic Reversion in DOCK8 Deficiency in One Patient With Two Novel Variants and Sclerosing Cholangitis. Front Immunol (2021) 12:673487. doi: 10.3389/fimmu.2021.673487

86. Fuchs S, Rensing-Ehl A, Pannicke U, Lorenz MR, Fisch P, Jeelall Y, et al. Omenn Syndrome Associated With a Functional Reversion Due to a Somatic Second-Site Mutation in CARD11 Deficiency. Blood (2015) 126:1658-69. doi: 10.1182/blood-2015-03-631374

87. Barnes MJ, Krebs P, Harris N, Eidenschenk C, Gonzalez-Quintial R, Arnold $\mathrm{CN}$, et al. Commitment to the Regulatory T Cell Lineage Requires CARMA1 in the Thymus But Not in the Periphery. PLoS Biol (2009) 7:e51. doi: 10.1371/journal.pbio.1000051

88. Molinero LL, Yang J, Gajewski T, Abraham C, Farrar MA, Alegre ML. CARMA1 Controls an Early Checkpoint in the Thymic Development of FoxP3 Regulatory T Cells. J Immunol (2009) 182:6736-43. doi: 10.4049/ jimmunol.0900498

89. Brigida I, Zoccolillo M, Cicalese MP, Pfajfer L, Barzaghi F, Scala S, et al. TCell Defects in Patients With ARPC1B Germline Mutations Account for Combined Immunodeficiency. Blood (2018) 132:2362-74. doi: 10.1182/ blood-2018-07-863431

90. Kuijpers TW, Tool ATJ, van der Bijl I, de Boer M, van Houdt M, de Cuyper $\mathrm{IM}$, et al. Combined Immunodeficiency With Severe Inflammation and Allergy Caused by ARPC1B Deficiency. J Allergy Clin Immunol (2017) 140:273-7.e10. doi: 10.1016/j.jaci.2016.09.061

91. Kahr WH, Pluthero FG, Elkadri A, Warner N, Drobac M, Chen CH, et al. Loss of the Arp2/3 Complex Component ARPC1B Causes Platelet Abnormalities and Predisposes to Inflammatory Disease. Nat Commun (2017) 8:14816. doi: 10.1038/ncomms14816

92. Volpi S, Cicalese MP, Tuijnenburg P, Tool ATJ, Cuadrado E, Abu-Halaweh $\mathrm{M}$, et al. A Combined Immunodeficiency With Severe Infections, Inflammation, and Allergy Caused by ARPC1B Deficiency. J Allergy Clin Immunol (2019) 143:2296-9. doi: 10.1016/j.jaci.2019.02.003

93. Randzavola LO, Strege K, Juzans M, Asano Y, Stinchcombe JC, GawdenBone CM, et al. Loss of ARPC1B Impairs Cytotoxic T Lymphocyte Maintenance and Cytolytic Activity. J Clin Invest (2019) 129:5600-14. doi: $10.1172 /$ JCI129388

94. Le Guen T, Touzot F, André-Schmutz I, Lagresle-Peyrou C, France B, Kermasson L, et al. An In Vivo Genetic Reversion Highlights the Crucial Role of Myb-Like, SWIRM, and MPN Domains 1 (MYSM1) in Human Hematopoiesis and Lymphocyte Differentiation. J Allergy Clin Immunol (2015) 136:1619-26.e5. doi: 10.1016/j.jaci.2015.06.008

95. Heusinkveld LE, Majumdar S, Gao JL, McDermott DH, Murphy PM. WHIM Syndrome: From Pathogenesis Towards Personalized Medicine and Cure. J Clin Immunol (2019) 39:532-56. doi: 10.1007/s10875-019-00665-w

96. Mcdermott DH, Gao JL, Murphy PM. Chromothriptic Cure of WHIM Syndrome: Implications for Bone Marrow Transplantation. Rare Dis (2015) 3:e1073430. doi: 10.1080/21675511.2015.1073430 
97. Ly P, Cleveand DW. Rebuilding Chromosomes After Catastrophe: Emerging Mechanisms of Chromothripsis. Trends Cell Biol (2017) 27:917-30. doi: 10.1016/j.tcb.2017.08.005

98. Catto LFB, Borges G, Pinto AL, Clé DV, Chahud F, Santana BA, et al. Somatic Genetic Rescue in Hematopoietic Cells in GATA2 Deficiency. Blood (2020) 136:1002-5. doi: 10.1182/blood.2020005538

99. Sullivan KE, Stiehm ER. Stiehm's Immune Deficiencies: Inborn Errors of Immunity. 2nd ed. New York: Academic Press (2020). p. 427-31.

100. Sullivan KE, Stiehm ER. Stiehm's Immune Deficiencies: Inborn Errors of Immunity. 2nd ed. New York: Academic Press (2020) p. 431-4.

101. Sahoo SS, Pastor VB, Goodings C, Voss RK, Kozyra EJ, Szvetnik A, et al. Clinical Evolution, Genetic Landscape and Trajectories of Clonal Hematopoiesis in SAMD9/SAMD9L Syndromes. Nat Med (2021) 27:180617. doi: 10.1038/s41591-021-01511-6

102. Narumi S, Amano N, Ishii T, Katsumata N, Muroya K, Adachi M, et al. SAMD9 Mutations Cause a Novel Multisystem Disorder, MIRAGE Syndrome, and Are Associated With Loss of Chromosome 7. Nat Genet (2016) 48:792-7. doi: 10.1038/ng.3569

103. Shima H, Koehler K, Nomura Y, Sugimoto K, Satoh A, Ogata T, et al. Two Patients With MIRAGE Syndrome Lacking Haematological Features: Role of Somatic Second-Site Reversion SAMD9 Mutations. J Med Genet (2018) 55:81-5. doi: 10.1136/jmedgenet-2017-105020

104. Chen DH, Below JE, Shimamura A, Keel SB, Matsushita M, Wolff J, et al. Ataxia-Pancytopenia Syndrome Is Caused by Missense Mutations in SAMD9L. Am J Hum Genet (2016) 98:1146-58. doi: 10.1016/j.ajhg.2016.04.009

105. Tesi B, Davidsson J, Voss M, Rahikkala E, Holmes TD, Chiang SCC, et al. Gain-Of-Function SAMD9L Mutations Cause a Syndrome of Cytopenia, Immunodeficiency, MDS, and Neurological Symptoms. Blood (2017) 129:2266-79. doi: 10.1182/blood-2016-10-743302

106. Schwartz JR, Wang S, Ma J, Lamprecht T, Walsh M, Song G, et al. Germline SAMD9 Mutation in Siblings With Monosomy 7 and Myelodysplastic Syndrome. Leukemia (2017) 31:1827-30. doi: 10.1038/leu.2017.142

107. Buonocore F, Kühnen P, Suntharalingham JP, Del Valle I, Digweed M, Stachelscheid $\mathrm{H}$, et al. Somatic Mutations and Progressive Monosomy Modify SAMD9-Related Phenotypes in Humans. J Clin Invest (2017) 127:1700-13. doi: 10.1172/JCI91913

108. Pastor VB, Sahoo SS, Boklan J, Schwabe GC, Saribeyoglu E, Strahm B, et al. Constitutional SAMD9L Mutations Cause Familial Myelodysplastic
Syndrome and Transient Monosomy 7. Haematologica (2018) 103:427-37. doi: 10.3324/haematol.2017.180778

109. Wong JC, Bryant V, Lamprecht T, Ma J, Walsh M, Schwartz J, et al. Germline SAMD9 and SAMD9L Mutations Are Associated With Extensive Genetic Evolution and Diverse Hematologic Outcomes. JCI Insight (2018) 3:e121086. doi: 10.1172 /jci.insight.121086

110. Roucher-Boulez F, Mallet D, Chatron N, Dijoud F, Gorduza DB, Bretones P, et al. Reversion SAMD9 Mutations Modifying Phenotypic Expression of MIRAGE Syndrome and Allowing Inheritance in a Usually De Novo Disorder. Front Endocrinol (Lausanne) (2019) 10:625. doi: 10.3389/ fendo.2019.00625

111. Gattinoni L, Speiser DE, Lichterfeld M, Bonini C. T Memory Stem Cells in Health and Disease. Nat Med (2017) 23:18-27. doi: 10.1038/nm.4241

112. Hamanoue S, Yagasaki H, Tsuruta T, Oda T, Yabe H, Yabe M, et al. Myeloid Lineage-Selective Growth of Revertant Cells in Fanconi Anaemia. $\mathrm{Br} J$ Haematol (2006) 132:630-5. doi: 10.1111/j.1365-2141.2005.05916.x

113. Van Horebeek L, Dubois B, Goris A. Somatic Variants: New Kids on the Block in Human Immunogenetics. Trends Genet (2019) 35:935-47. doi: 10.1016/j.tig.2019.09.005

Conflict of Interest: The authors declare that the research was conducted in the absence of any commercial or financial relationships that could be construed as a potential conflict of interest.

The handling editor declared a past collaboration with one of the authors, TW.

Publisher's Note: All claims expressed in this article are solely those of the authors and do not necessarily represent those of their affiliated organizations, or those of the publisher, the editors and the reviewers. Any product that may be evaluated in this article, or claim that may be made by its manufacturer, is not guaranteed or endorsed by the publisher.

Copyright (c) 2021 Miyazawa and Wada. This is an open-access article distributed under the terms of the Creative Commons Attribution License (CC BY). The use, distribution or reproduction in other forums is permitted, provided the original author(s) and the copyright owner(s) are credited and that the original publication in this journal is cited, in accordance with accepted academic practice. No use, distribution or reproduction is permitted which does not comply with these terms. 